\title{
1 Trace elements in grey seals from the Gulf of St.
}

2 Lawrence

4 Gwyneth A. MacMillan ${ }^{a}$; Marc Amyot ${ }^{\mathrm{b}}$; Pierre-Yves Daoust ${ }^{\mathrm{c}}$; Mélanie Lemire ${ }^{\mathrm{d}}$

5 a Department of Natural Resource Sciences, McGill University, Sainte-Anne-de-Bellevue,

6 Québec, H9X 3V9, Canada. E-Mail: gwyneth.macmillan@mail.mcgill.ca

7 b Centre d'études nordiques, Département de sciences biologiques, Université de Montréal,

8 Montréal, QC, H3C 3J7, Canada. E-Mail: m.amyot@umontreal.ca

$9{ }^{\mathrm{c}}$ Canadian Wildlife Health Cooperative, Atlantic Veterinary College, University of Prince

10 Edward Island, Charlottetown, PE, C1A 4P3, Canada. E-Mail: daoust@upei.ca

$11{ }^{\mathrm{d}}$ Corresponding author: Mélanie Lemire, Centre de recherche du CHU de Québec -Université

12 Laval, Département de médecine sociale et préventive, Institut de biologie intégrative et des

13 systèmes (IBIS), Université Laval, Québec G1V 0A6, QC, Canada. E-Mail :

14 melanie.lemire@crchudequebec.ulaval.ca.

CRediT AUTHOR STATEMENT. Gwyneth A. MacMillan: Formal Analysis, Writing -

17 Original Draft, Visualization. Marc Amyot: Supervision, Validation, Writing - Review \&

18 Editing. Pierre-Yves Daoust: Conceptualization, Methodology, Investigation, Funding

19 Acquisition, Writing - Review \& Editing. Mélanie Lemire: Supervision, Validation, Funding

20 Acquisition, Writing - Review \& Editing.

Keywords : pinnipeds, gray seal, Halichoerus grypus, metals, mercury, methylmercury

Declaration of Competing Interest. The authors declare that they have no known competing

25 financial interests or personal relationships that influenced the work reported in this paper. 


\section{HIGHLIGHTS}

1. We measured baseline levels of 19 trace elements in grey seals harvested from the Gulf of St. Lawrence.

2. We evaluated nutritional benefits and health concerns of human consumption of grey seal products.

3. Once seals began feeding at sea ( $\sim 5 \mathrm{mo})$, many element concentrations increased, but did not bioaccumulate progressively with age afterwards.

4. Some elements were more concentrated in the muscle (mercury) and livers (manganese, zinc) of male seals.

5. Young seal $(<6 \mathrm{we})$ livers are a good dietary sources of copper and iron, while its muscle and liver were below reference values for toxic elements.

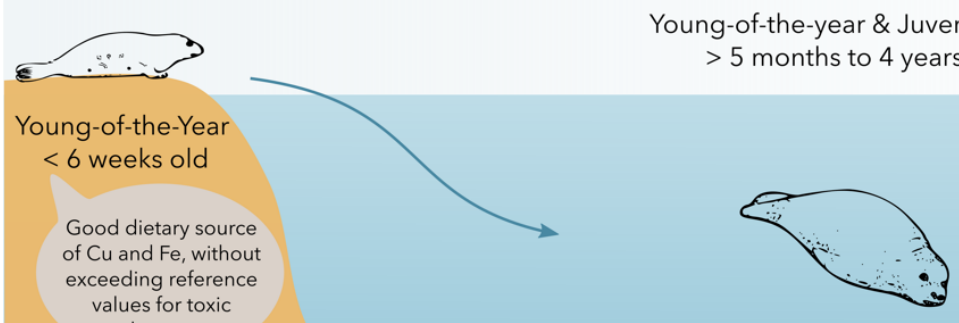

alues for toxic elements

Concentrations of Essential and Non-Essential Trace Elements

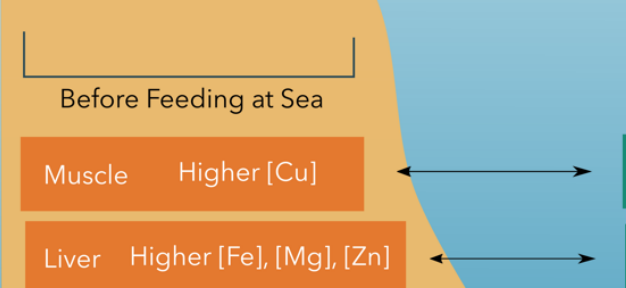

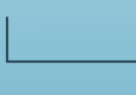

Muscle

All Seals Feeding at Sea

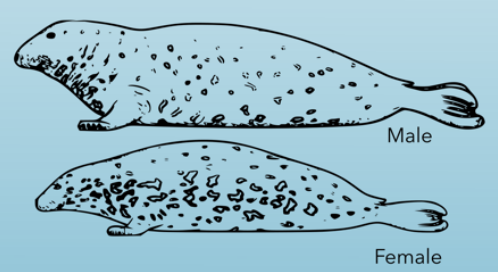

\section{Liver \\ Higher [Cd], [Se], [THg], [MeHg]}




\section{ABSTRACT}

We measured baseline levels of 19 trace element and mercury speciation for grey seals (Halichoerus grypus) from the Gulf of St. Lawrence (GSL), Québec, Canada. With interest growing in commercializing grey seal products for human consumption in this region, the goal of

44 this study was to measure essential and non-essential trace elements in grey seals to evaluate health concerns and nutritional benefits. From 2015 to 2019, 120 grey seals were sampled by hunters and researchers at 4 sites in the GSL. Muscle, liver, heart and kidney samples were analyzed for 10 non-essential elements (Sb, As, Be, B, Cd, Pb, Hg, Ni, Tl, Sn) and 9 essential elements (Co, Cr, Cu, Fe, Mg, Mn, Mo, Se, Zn). Both total mercury (THg) and methylmercury (MeHg) were analysed for a subset of samples. Many elements were undetected in liver (Sb, As, $\mathrm{Be}, \mathrm{B}, \mathrm{Cr}, \mathrm{Co}, \mathrm{Pb}, \mathrm{Ni}, \mathrm{Tl}, \mathrm{Sn}$ ) and muscle tissues (same, plus Cd, Mn, Mo). Results showed lower element concentrations in the muscle (Fe, $\mathrm{Mg}, \mathrm{Se})$ and livers (Cd, $\mathrm{Cr}, \mathrm{Hg}, \mathrm{Mn}, \mathrm{Mo}, \mathrm{Se}$ ) of

52 young-of-the-year harvested in the winter ( $<6$ weeks old) compared to older animals feeding at

53 sea. For older seals ( $\sim 5$ months to 29 years), we did not observe progressive age-dependent

54 bioaccumulation. Sex-specific differences were not very pronounced, but a few elements were 30

$55-70 \%$ higher in the muscle $(\mathrm{THg}, \mathrm{MeHg})$ and liver $(\mathrm{Mn}, \mathrm{Zn})$ of male seals. Comparison to

56 Canadian dietary reference intakes shows that a weekly portion of liver from young-of-the-year

57 ( $<6$ weeks old) is a good source of essential elements $(\mathrm{Cu}, \mathrm{Fe})$ and that muscle and liver from

58 this age category does not exceed reference values for toxic elements ( $\mathrm{As}, \mathrm{Cd}, \mathrm{Pb}, \mathrm{MeHg}$ ).

59 Ongoing discussions with regional public health professionals will help to develop dietary recommendations for the consumption of older grey seals. 


\section{INTRODUCTION}

There is currently growing interest in the commercial exploitation of grey seals (Halichoerus grypus) from the Gulf of St. Lawrence, Canada. Seal hunting is a cultural tradition in the region and an important economy for many fishermen in the Magdalen Islands, Québec, located in the Gulf of St. Lawrence (GSL) (Pintal, 2003; Baril and Breton, 1982). Until the 19th century, Magdalen Islanders practiced a subsistence seal hunt for meat, oil and clothing, and, today, small businesses have developed new uses and markets for grey seal products with the goals of promoting local benefits and sound resource management (ACPIQ, 2021). Grey seals in eastern Canadian waters compose a single genetic population estimated to number 424,300 individuals in 2016 and distributed across 3 breeding areas: Sable Island off Nova Scotia, coastal areas of Nova Scotia, and the GSL (Hammill et al., 2017). Since the end of an intensive hunt in the 1960s, the population has been slowly increasing and increased predation by grey seals may be impacting the recovery of cod and other groundfish stocks which collapsed due to overfishing (Hammill et al., 2014; Swain et al., 2019)). The total allowable catch for grey seals in Canada is set at 60,000, however only 1,612 seals were harvested commercially in 2016 which is less than $1 \%$ of the Northwest Atlantic population (Government of Canada, 2016a). The Committee on the Status of Endangered Wildlife in Canada (COSEWIC) has designated the grey seal as "not at risk" since 1999.

In the Northwest Atlantic, grey seal pups are born between December and February on land or ice. Unlike harp seals (Pagophylus groenlandicus), grey seals do not need access to pack ice to give birth. Most pups (85\%) are born on Sable Island, and the rest are born in the GSL (11\%) and along the Eastern Shore of Nova Scotia (4\%). The distribution of pups has changed over time, with a decline in the proportion born on ice in the GSL and an increase on Sable Island and the Eastern Shore (Government of Canada, 2016b). Pups are weaned at about 2-3 weeks but remain after on land until about 40 days, when they head out to sea to feed after a post-weaning fast (Noren et al., 2008). Once at sea, grey seals are mobile, generalist predators that feed on demersal fish such as cod, American plaice, and sand lance, as well as small pelagic fish such as herring and mackerel. Grey seal diets can vary by geography, season, and sex (Hammill et al., 2014). Grey seals seem to occupy an intermediate trophic level compared to other seals and marine mammals in the Estuary and GSL. Previous studies indicate that hooded 
seals (Cystophora cristata) occupy a higher trophic level than grey seals, whereas harp seals and beluga whales (Delphinapterus leucas) in the region occupy lower trophic levels (Lesage et al., 2001; Morissette et al., 2006).

Commercial hunts for grey seals are currently centered around the Magdalen Islands and in the southern GSL and primarily target post-weaned young-of-the-year (YY) less than 6 weeks old for meat, fat, and internal organs, although juvenile and adult seals are also sometimes hunted for meat. For predators at the top of marine food webs, such as seals, the processes of bioaccumulation and biomagnification can lead to higher concentrations of some trace elements (AMAP, 2018). Essential trace elements, such as copper and iron, are necessary for the proper biological functioning of organisms but can reach high concentrations harmful to the health of organisms or those who consume them. Non-essential trace elements, such as mercury, cadmium and lead, have no biological function and can be toxic at very low concentrations for human consumers, especially during pregnancy and for young children (Fraga, 2005). consumption of grey seal products, the objective of this study was to measure baseline concentrations of several essential and non-essential trace elements in grey seals harvested from the GSL. For this study, 120 grey seals of different ages were sampled from 2015 to 2019 at four different sites in the GSL. More specifically, we wanted to evaluate the i) influence of age category (YY, juvenile, adult), exact age (years), sex, sampling site and tissue type (muscle,

110 liver, kidney, heart) on trace element concentrations and ii) compare values measured in grey

111 seals with Canadian dietary reference intakes and reference values for essential and non-essential 112 elements respectively.

\section{2. MATERIAL \& METHODS}

\section{$114 \quad 2.1$ Sample collection}

From 2015 to 2019, 120 grey seals were harvested during commercial or scientific

116 sampling at two sites near the Magdalen Islands $\left(47.3877^{\circ} \mathrm{N}, 61.9012^{\circ} \mathrm{W}\right)$ and two sites in the

117 Northumberland Strait $\left(45.9713^{\circ} \mathrm{N}, 63.5608^{\circ} \mathrm{W}\right)$ in the GSL, Canada (Fig. 1). Grey seals

118 harvested during scientific sampling were collected under permits QUE-Research Notice IML

119 2015-19, IML 2017-01, and QUE-SCIENTIFIQUE-069-2018. The sampling during commercial 
120 hunts were collected under Department of Fisheries and Oceans (DFO) permits IM 2015-01, IM

121 2017-01, and IM 2018-01. Sample handling was authorized by the UPEI Biosafety Committee

122 (protocol 6006710). Sample collection was coordinated by the Association des chasseurs de

123 phoques Intra-Québec (ACPIQ), the Ministère de l'Agriculture, des Pêcheries et de

124 l'Alimentation du Québec (MAPAQ) and the Maurice-Lamontagne Institute of Fisheries and

125 Oceans Canada.

126 Samples were collected in two distinct groups. The first group (Group 1) consisted of 89

127 seals harvested in January and February of 2015, 2017 and 2018 at four sites designated Islands

1281 to 4 . Note that Island 4 was sampled as a comparison and no commercial seal hunting is

129 conducted at this location. Only muscle and liver tissues were collected from this group of seals

130 which included 36 winter YY, 6 juveniles, and 48 adults (Fig. 1). Muscle tissue was collected

131 from inside the abdomen to avoid contamination from bullet fragments, except for samples from

1322015 which were taken from several places on the carcass. A second group (Group 2) of 31

133 samples were collected from sub-adult seals harvested near Island 1 in June 2019. Muscle, heart

134 and kidney (but not liver) tissue samples were collected from this group of 20 spring YY and 11

135 juveniles. For both groups, about $50 \mathrm{~g}$ of each tissue were collected from each seal. All samples

136 were kept cold during transport and were frozen at $-20^{\circ} \mathrm{C}$ less than 24 hours after collection.

137 During commercial expeditions, recently weaned young-of-the-year $(<6$ weeks $)$ were

138 harvested on dry land using a hakapik and older seals (> 5 months) were harvested in the water

139 using a high caliber rifle from a small motorboat. During scientific expeditions, adult seals were

140 also harvested on dry land using a high caliber rifle. Sex was determined at the time of sampling

141 and seals were initially classified into 3 age categories based on size and fur appearance; young-

142 of-the-year (YY, < 1 year), juvenile (1 - 4 years) or adult ( $>4$ years). The exact age was

143 estimated for a sub-sample of seals $(n=54)$ by counting the annual growth layers in the

144 cementum of canine teeth (Frie et al., 2013). Due to the difference in sampling dates (winter vs.

145 spring) for the two groups, seals were subsequently grouped into 4 age categories based on

146 sampling date and canine analysis; winter young-of-the-year (winter YY, $<6$ weeks old), spring

147 young-of-the-year (spring YY, 5-6 months old), juvenile (1 - 4 years), or adult ( $>4$ years). 


\subsection{Laboratory analysis}

For Group 1, muscle $(\mathrm{n}=88)$ and liver $(\mathrm{n}=89)$ samples were analyzed for 9 essential trace elements: chromium $(\mathrm{Cr})$, cobalt $(\mathrm{Co})$, copper $(\mathrm{Cu})$, iron $(\mathrm{Fe})$, magnesium $(\mathrm{Mg})$, manganese (Mn), molybdenum (Mo), selenium (Se), zinc ( $\mathrm{Zn})$, and 10 non-essential elements: antimony ( $\mathrm{Sb})$, arsenic (As), beryllium (Be), boron (B), cadmium (Cd), lead ( $\mathrm{Pb})$, mercury $(\mathrm{Hg})$, nickel (Ni), thallium (Tl), and tin (Sn). For Group 2, muscle, heart and kidney samples (n = 31) were analyzed for the same 19 elements. Trace elements were analyzed at the Animal Health Laboratory, Laboratory Services Division, University of Guelph, Ontario, Canada. Complete samples (about $50 \mathrm{~g}$ ) were cut in half and a sub-sample of tissue was taken from the freshly exposed portion to avoid contamination from outside surfaces. Non-homogenized wet tissue samples (about $1 \mathrm{~g}$ ) were weighed and digested with nitric acid in a microwave (CEM MARSXpress) and then diluted with Nanopure water before analysis by Inductively Coupled Plasma - Mass Spectrometry (ICP-MS). Detection limits (LOD) and detection frequencies (percentage of samples $>$ LOD) are shown in Table S1. Note that LOD were lower for samples from Group 2 because the two groups of samples were analysed on different instruments (Group 1 - 820 MS, Varian Inc. Palo Alto, CA, USA; Group 2 - 7900 ICP-MS, Agilent, Santa Clara, CA, USA).

Total mercury (THg) and methylmercury (MeHg) were analysed for a sub-sample from

166 Group 1 (muscle : $\mathrm{n}=32$, liver : $\mathrm{n}=43$ ) and all samples from Group 2 (muscle, heart and kidney $: \mathrm{n}=31$ ). Analyses were conducted at the laboratory of the Chaire de recherche $d u$ Canada en écotoxicologie et changements mondiaux, Université de Montréal, Québec, Canada (Table S1).

169 Tissue samples were freeze-dried and homogenized before analysis following trace metal clean

170 protocols. Tissue THg was analyzed using two different methods. The least concentrated samples

171 (all muscle, heart, and kidney tissues, as well as liver tissue from young-of-the-year) were

172 analyzed by cold vapour atomic absorption spectrometry with a Direct Mercury Analyzer

173 (DMA-80, Milestone Inc, Shelton, CT, USA). The more concentrated samples (all liver samples,

174 except for young-of-the-year) were analyzed using cold-vapor atomic fluorescence spectrometry

175 (CV-AFS). For this analysis, samples were diluted and analyzed with a Tekran 2600 using EPA

176 Method 1631. Tissues MeHg was analyzed by CV-AFS with a Tekran 2700 using EPA method

1771630 (Tekran Instruments Corporation, Seattle, WA, USA). Concentrations were converted from

178 dry weight to wet weight using the percent humidity of each sample. Percent humidity was $70 \pm$ 
$2.6 \%, 70 \pm 1.9 \%, 77 \pm 0.9 \%$, and $77 \pm 0.9 \%$ (mean $\pm \mathrm{SD})$ for samples of muscle, liver, heart and kidney respectively.

Analytical blanks, duplicate samples, an internal control (bovine liver), and a certified reference material (Tort-3 - lobster hepatopancreas; NRC Canada) were included after each set of 40 samples during trace element analysis at the University of Guelph (Table S2). Internal or certified standards were used to validate instrument drift during analysis. Acceptable limits for duplicate samples were $20 \%$ for elements measured at more than twice the LOD and recovery varied from 2 to $16 \%$. For the $\mathrm{THg}$ and $\mathrm{MeHg}$ analyses at the Université de Montréal, analytical blanks, internal controls (CALA-4 - water; Canadian Association for Laboratory Accreditation), and certified reference materials (Tort-2 - lobster hepatopancreas, Dorm-4/Dorm-2 - fish tissue, and SO-2 - soil; NRC Canada) were analysed after each 10-12 samples. Reference material measurement fell within the range of certified values for all analyses (Table S3). A sub-sample of muscle $(\mathrm{n}=32)$ and liver $(\mathrm{n}=45)$ samples from Group 1 and all samples from Group $2(\mathrm{n}=$ 31) were analyzed for THg at both laboratories in this study. Correspondence between analyses was acceptable with an average difference of $4.9 \%$ (Table S4). To maximize sample size in this study, all reported values for THg are taken from analyses by ICP-MS at the University of Guelph. One exception to this was when reporting $\mathrm{MeHg}$ values, which were compared to the corresponding THg value from the same analysis batch at the Université de Montréal to improve the accuracy of measurements.

\subsection{Data handling and statistical analysis}

Trace element concentrations were not normally distributed and therefore geometric means (GM), which are the antilogarithm of the mean of the logarithmic values for each sample, were used to show the central tendency of the data. The $95 \%$ confidence intervals $(95 \% \mathrm{CI})$ are also reported. All concentrations are shown on a wet weight (w.w.) basis. Sample concentrations under the LOD were replaced with half the LOD. An analyte was considered "detected" if more than $60 \%$ of samples were higher than the detection limits (LOD) of the instrument, and GM and 95\% CI were only reported for detected elements.

One-way Student's t-tests (independent samples) and one-way analysis of variance (ANOVA) followed by Tukey HSD post-hoc tests were used to evaluate differences in trace element concentrations independently by tissue type, age category, sex, and sample site. 
209 Pearson's r correlations were used to determine the relationship between variables, including

210 exact age (years) vs. trace element concentrations and Se vs. THg concentrations. Unbalanced

211 two-way ANOVAs were used to test the relative effect of sex and age category on $\mathrm{THg}$ and

$212 \mathrm{MeHg}$ concentrations in muscle and liver tissues. All statistical tests were performed using $\log _{10^{-}}$

213 transformed concentrations and a threshold of $\alpha$ equals 0.05 in "R" software (R Core Team,

214 2020). Graphics were created with the 'ggplot2' package (Hadley, 2016).

215 Concentrations of non-essential trace elements were compared to reference values

216 established by Health Canada for chemical contaminants in food (Canada, 2005a). Reference

217 values are intended to prevent excessive exposure to contaminants for the most vulnerable

218 populations, usually pregnant or nursing women and young children, while maximizing the

219 health benefits of consuming the food item. For mercury, the reference values of 0.5 and $1.0 \mu \mathrm{g}$

$220 \mathrm{Hg} / \mathrm{g}$ for commercially sold fish products are calculated from the provisional Tolerable Daily

221 Intake (pTDI) of $0.47 \mu \mathrm{g} \mathrm{Hg} / \mathrm{kg}$ of body weight for the general population and of $0.2 \mu \mathrm{g} \mathrm{Hg} / \mathrm{kg}$

222 of body weight for young children and pregnant women (including women of childbearing age,

223 those who plan to become pregnant, and breastfeeding women). This correspond to dietary

224 recommendations of a maximum of $150 \mathrm{~g}$ per week for pregnant women and $75 \mathrm{~g}$ per week for

225 children aged 1 to 4 years, equivalent to 1 or 2 portion sizes, of a food item with about $0.5 \mu \mathrm{g}$

$226 \mathrm{Hg} / \mathrm{g}$ (but below the reference value of $1.0 \mu \mathrm{g} \mathrm{Hg} / \mathrm{g}$ ) (Canada, 2007).

227 Concentrations of essential trace elements were compared to Health Canada's Dietary

228 Reference Intake Tables (Canada, 2005b) using four scenarios for two population subgroups

229 vulnerable to trace element toxicity, 1) children aged 1 to 3 years and 2) pregnant women aged

23019 to 30 years (including those who plan to become pregnant and those who are breastfeeding).

231 Recommended Dietary Allowances (RDA), Adequate Intake (AI) and Tolerable Upper Intake

232 Level (UL) values were calculated for a weekly consumption of $150 \mathrm{~g}$ (pregnant women) or $75 \mathrm{~g}$

233 (children) of adult seal muscle or liver, as well as winter YY ( $<6$ weeks old) muscle or liver.

234 Scenarios were not calculated for heart and kidney tissues because essential elements

235 concentrations in these tissues were intermediate between muscle and liver tissues. 


\section{RESULTS}

\subsection{Trace element concentrations}

Mean concentrations of trace elements in grey seal tissues are shown as a function of age category, sex, sample site and tissue type with ANOVA and post-hoc results in the

240 Supplementary Material (Tables S5 to S13). Many of the trace elements measured in this study 241 were not detected in liver ( $\mathrm{Sb}, \mathrm{As}, \mathrm{Be}, \mathrm{B}, \mathrm{Cr}, \mathrm{Co}, \mathrm{Pb}, \mathrm{Ni}, \mathrm{Tl}, \mathrm{Sn}$ ) or muscle tissues (same

242 elements as liver, plus Cd, Mn, Mo) for the first group of seal samples (Group 1). For the second 243 group of samples (Group 2), detected elements were the same as for Group 1 plus As (muscle, 244 heart, kidney), and $\mathrm{Cd}, \mathrm{Co}$ and $\mathrm{Pb}$ (kidney) which were also detected because of lower analytical 245 LOD for Group 2 analyses (Table S1). Results for $\mathrm{Hg}$ and $\mathrm{MeHg}$ are detailed separately in 246 Section 3.2.

\subsubsection{Age differences}

For muscle and liver tissues, the concentration of many of the detected trace elements

249 varied significantly with seal age category (Table 1). For muscle tissues, Fe, $\mathrm{Mg}$, and $\mathrm{Se}$

250 concentrations were significantly lower in winter YY ( $<6$ weeks old) when compared to spring

251 YY (5 - 6 months old), juveniles ( 1 - 4 years) and adults ( $>4$ years). Muscle Cu concentrations

252 were about $20 \%$ higher in winter and spring YY when compared to juveniles and adults. No 253 trend was observed for $\mathrm{Zn}$ in muscle tissue (Table S5). For liver tissues, concentrations of Cd, 254 Cr, Mn, Mo and Se were also lower in winter YY ( $<6$ weeks old) when compared to juveniles 255 and adults. Conversely, concentrations of 3 essential elements ( $\mathrm{Fe}, \mathrm{Mg}, \mathrm{Zn}$ ) were higher in the 256 livers of winter YY compared to juveniles and adults. Hepatic concentrations of $\mathrm{Pb}$ and $\mathrm{Cu}$ did 257 not vary significantly with age category (Table S6). Liver samples were not collected from 258 spring YY (<6 months old) in Group 2 and we could not thoroughly test variation in kidney and 259 heart concentrations by age category because only two categories were represented in Group 2 260 (spring YY and juveniles). For the majority of elements, no significant difference in hepatic or 261 renal concentration were found between spring YY and juveniles, with the exception of Cd and 262 Se which were significantly lower (24\% and 83\% respectively) in the kidneys of spring YY 263 compared to juvenile seals (Table S7). 
The exact age of a subset of seals $(n=54)$ was determined by the number of tooth cementum layers in the canines. For 23 adult seals (19 males, 4 females) from Group 1, seal age ranged from 11 to 29 years old. All seals from Group $2(n=31)$ were analyzed for exact age and there were 11 juveniles in this group (aged 1.5 to 3.5 years) and 20 spring YY (aged 5 or 6 months). No significant associations were observed between exact age (years) and trace element concentrations $(\mathrm{Cd}, \mathrm{Cr}, \mathrm{Cu}, \mathrm{Fe}, \mathrm{Mg}, \mathrm{Mn}, \mathrm{Mo}, \mathrm{Se})$ in muscle $(\mathrm{n}=54)$ or liver $(\mathrm{n}=23)$ tissues for this subset of seals (Fig. 2), with one exception for Zn muscle concentrations, however Zn trends with exact age were not significant when testing adult seals only (Pearson's $r$ correlations, Table S14).

\subsubsection{Sex and site-specific differences}

Trace element concentrations were analyzed as a function of sex and sampling site for muscle and liver tissues from a subset of juvenile and adult seals from Group 1 (muscle : $\mathrm{n}=65$, liver : $n=54)$. This subset was selected to reduce variation due to seal age category and because seals from Group 2 were all collected from the same site (Island 1). Hepatic Mn and Zn were more concentrated in male seals but no differences were observed for muscle tissues, except for mercury (see section 3.2.1) (Table S10-S11). No other significant differences were observed between the sexes. For sample site, trace elements concentrations were highly variable between sites. Higher concentrations of some elements were observed in muscle $(\mathrm{Cu})$ and liver $(\mathrm{Cr}, \mathrm{Fe}$, $\mathrm{Se}, \mathrm{Zn}$ ) tissues from seals harvested at Island 4 (Table S12-S13).

\subsubsection{Tissue-specific differences}

More elements were detected in liver (8) compared to muscle (5) tissues across all age categories, indicating that several elements $(\mathrm{Cd}, \mathrm{Mn}, \mathrm{Mo})$ were more concentrated in the liver. For elements detected in both tissues ( $\mathrm{Cu}, \mathrm{Co}, \mathrm{Fe}, \mathrm{Mg}, \mathrm{Se}, \mathrm{Zn})$, average hepatic concentrations were 1.8 to 35 times higher compared to muscle tissue (adults only, Student's t-test, $\mathrm{p} \leq 0.001$ ),

288 with the exception of $\mathrm{Mg}$ which was more concentrated in the muscle $(\mathrm{t}=12.37, \mathrm{p} \leq 0.001)$. For

289 the muscle, heart and kidney samples harvested from spring YY and juvenile seals (Group 2

290 samples), several elements were only detected in the kidneys (Cd, Co, Pb) (Table S1). As and $\mathrm{Cu}$

291 concentrations were 2-fold higher in hearts and kidneys compared to muscle samples, whereas

292 the reverse was true for $\mathrm{Fe}$. For $\mathrm{Pb}$, the majority of muscle, liver and heart concentrations were

293 below the LOD $(<0.01 \mu \mathrm{g} / \mathrm{g}$ for Group $1 ;<0.005 \mu \mathrm{g} / \mathrm{g}$ for Group 2$)$. When detected, $\mathrm{Pb}$ 
294 concentrations ranged from $0.006-0.48 \mu \mathrm{g} / \mathrm{g}$ in muscle and from $0.01-0.05 \mu \mathrm{g} / \mathrm{g}$ in liver. Renal

$295 \mathrm{~Pb}$ was detected in the majority (94\%) of samples and ranged from $0.005-0.22 \mu \mathrm{g} / \mathrm{g}$ (Group 2).

296 There were 8 outliers for $\mathrm{Pb}$ in seal muscle and 3 outliers in heart tissues (Fig. 3)

297 For the other elements (Mg, Mn, Hg, Mo, Se, Zn), concentrations varied significantly

298 between muscle, heart and kidney tissues without showing a general trend. For example, Mg and

299 Zn concentrations increased in the order kidney $<$ heart $<$ muscle, but in the opposite order for

300 Mn. Since liver was not sampled for Group 2, hepatic concentrations from juvenile seals in

301 Group $1(n=6)$ were compared with heart and kidney concentrations in juveniles from Group 2

$302(\mathrm{n}=11)$. The majority of trace elements $(\mathrm{Cu}, \mathrm{Fe}, \mathrm{Mn}, \mathrm{Hg}, \mathrm{Se}, \mathrm{Zn})$ were more concentrated in the

303 liver than in hearts or kidneys for these juvenile seals, with the exception of $\mathrm{Mg}$ which increased

304 in the order kidney $<$ heart $=$ liver $<$ muscle $(\mathrm{p} \leq 0.001)$. Renal Cd concentrations were

305 significantly higher compared to liver samples for juvenile seals $(2.44 \mu \mathrm{g} / \mathrm{g}$ versus $1.00 \mu \mathrm{g} / \mathrm{g}$

306 respectively).

\subsection{Mercury and methylmercury}

\subsubsection{Age-, sex- and site- specific differences}

Similar to the other trace elements, $\mathrm{THg}$ and $\mathrm{MeHg}$ concentrations were significantly

310 lower in winter YY ( $<6$ weeks old) compared to other age categories for both muscle and liver

311 tissues (Table 2, Fig. 4, Table S8). No significant differences were observed for THg and MeHg

312 in hearts and kidneys for spring YY and juvenile seals (with one exception, Table S9). No

313 significant correlations were observed between exact age (years) and the concentrations of $\mathrm{THg}$

314 and MeHg in muscle and liver tissues (Fig. 2). However, significant differences were observed in

$315 \mathrm{THg}$ and $\mathrm{MeHg}$ concentrations between the sexes. On average, $\mathrm{THg}$ and $\mathrm{MeHg}$ were more

316 concentrated in the muscle tissues of adult and juvenile male seals. Average muscle

317 concentrations were $0.39 \mu \mathrm{g} \mathrm{THg} / \mathrm{g}$ and $0.43 \mu \mathrm{g} \mathrm{MeHg} / \mathrm{g}$ for male seals and these concentrations

318 were $1.6(\mathrm{THg})$ and $1.7(\mathrm{MeHg})$ times higher than in female seals (Table S10). No significant

319 differences by sex were found for liver tissues. For sample site, THg concentrations were higher

320 in muscle and liver tissues of seals collected on Island 4, when compared to Island 1 and 2 (p $<$

3210.01 , but no difference with Island 3). Among all samples, there were 4 adult seals (2 males and

3222 females) with THg concentrations greater than $100 \mu \mathrm{g} / \mathrm{g}$ in the liver: 2 were from Island 4, 1 

concentrations in muscle or liver among sample sites (Tables S12-13). relative importance of sex (male, female) and age (4 categories) on mercury concentration in seal tissues. Sample site could not be included as a factor in the multivariate model because of the unbalanced study design, i.e., all age categories were not sampled at each location. For THg in muscle tissues, both age category and sex were statistically significant $(\mathrm{p}<0.01)$. The effect size of age category was 0.382 , indicating that $38.2 \%$ of the variation of $\mathrm{THg}$ concentration in muscle

331 tissues was explained by age category $(\mathrm{F}=29.4, \mathrm{p}<0.001)$, more specifically by the difference

332 in concentrations between winter YY and all other categories (with no difference between the 333 other categories) (Tukey HSD, $\mathrm{p}<0.001$ ). Effect size for sex was 0.034 , indicating that only

$3343.4 \%$ of the variation in THg in muscle was explained by sex $(F=7.89, p=0.006)$, hence by the

335 higher concentrations found in male seals (Tukey HSD, $\mathrm{p}<0.001$ ). For THg in liver tissues, only 336 age category was significant $(\mathrm{F}=123.2, \mathrm{p}<0.001)$ with an effect size of 0.651 or $65.1 \%$

337 explained by lower THg concentrations found in winter YY ( $<6$ weeks old). Models for $\mathrm{MeHg}$ 338 concentration in muscle and liver tissues were very similar to models for $\mathrm{THg}$. For $\mathrm{MeHg}$ in seal 339 muscle, both variables were significant and the effect size for age category was 46.9\% ( $\mathrm{F}=22.9$, $340 \mathrm{p}<0.001)$, which was well above the $3.8 \%$ effect size for $\operatorname{sex}(\mathrm{F}=5.56, \mathrm{p}=0.022)$. For hepatic $341 \mathrm{MeHg}$, only age category was significant $(\mathrm{F}=21.2, \mathrm{p}<0.001)$ with an effect size of $47.1 \%$.

342 None of the interaction terms from the multivariate models were significant $(\mathrm{p}>0.05)$ indicating that there was no combined effect of age category and sex on $\mathrm{THg}$ or $\mathrm{MeHg}$ concentrations.

\subsubsection{Tissue-specific differences}

Regardless of age category, hepatic THg concentrations were higher (31-fold on average) compared to muscle tissues in the same seal. As shown in Table 2, after grouping all age

347 categories together (except winter YY to control for age-specific differences), $\mathrm{THg}$

348 concentrations increased in the following order: heart $<$ muscle $<$ kidney $<$ liver, with an

349 approximately 100-fold difference between heart and liver tissues $(\mathrm{F}=521.3, \mathrm{p}<0.001) . \mathrm{MeHg}$

350 concentrations were much less variable among the different tissues (Table 2). Considering all age 351 categories (except winter YY), MeHg concentrations were significantly lower in heart tissues 352 compared to the other tissue types $(\mathrm{F}=22.64, \mathrm{p}<0.001)$. THg and Se showed a very strong 
positive correlation in the liver $(r=0.97, p<0.01)$ but less so in the muscle $(r=0.46, p<0.01)$, heart $(\mathrm{r}=0.36, \mathrm{p}=0.04)$ and kidney $(\mathrm{r}=0.39, \mathrm{p}=0.03)$. MeHg and Se were likewise strongly correlated in the liver $(r=0.85, \mathrm{p}<0.01)$, less strongly so in the heart $(\mathrm{r}=0.45, \mathrm{p}=0.01)$, and were not correlated in muscle $(r=0.10, p=0.41)$ or kidney $(r=0.21, p=0.26)$ tissues.

The percentage of total mercury as methylmercury $(\% \mathrm{MeHg})$ was calculated for different tissues by age category (Tables S8- S9). Across all age categories, \% MeHg averaged 83\% (range: 62 - 100\%) in muscle tissues. The \% MeHg was much lower in liver tissues (3.4 \%) and more variable with seal age (range: 0.3 - $40 \%$ ). For heart tissues, the \% $\mathrm{MeHg}$ was similar to muscle tissues and averaged $88 \%$ (range: 77 - $97 \%$ ) and in the kidneys, average \% $\mathrm{MeHg}$ was $33 \%$ (range: 16 - $53 \%$ ). Percent MeHg also varied significantly with age category (Fig. 4).

363 For muscle tissues, average \% MeHg was significantly lower in winter YY (76 \%) compared to 364 spring YY and juvenile seals $(87 \%)(p=0.0029)$, but was not different from adult seals whose in winter YY (24\%, range 21 - $28 \%$ ) compared to juveniles and adults whose $\% \mathrm{MeHg}$ was very low $(<5 \%)$. The $\% \mathrm{MeHg}$ also decreased with age in the kidneys with an average of $38 \%$ in spring YY to $26 \%$ in juvenile seals $(\mathrm{p}<0.001)$ (Tables S8-S9).

\subsection{Comparison with Reference Values}

\subsubsection{Reference values for essential trace elements}

For essential trace elements detected in grey seal tissues in this study $(\mathrm{Cr}, \mathrm{Cu}, \mathrm{Fe}, \mathrm{Mg}$, Mn, Mo, Se, Zn), the Percent Dietary Reference Intakes (\% DRI) were calculated for two

373 vulnerable human population subgroups using four consumption scenarios (Table 3, Table S15).

374 Recommended Dietary Allowances (RDA), Adequate Intake (AI) and Tolerable Upper Intake

375 Level (UL) values were calculated for grey seal muscle and liver tissues from adult seals $(>4$ 376 years) and from winter young-of-the-year (winter YY, $<6$ weeks) based on weekly consumption

377 of $75 \mathrm{~g}$ of seal tissue for children 1-3 years old and $150 \mathrm{~g}$ of seal tissue per week for pregnant 378 women 19 - 30 years old.

379 Based on the \% RDA values, essential trace elements concentrations in muscle tissues 380 from seals of either age category would contribute less than $30 \%$ of the recommended intake 381 values for both pregnant women and young children. This means that the consumption of a 382 weekly portion of seal muscle harvested from either adult or YY seals would provide less than 
383 the minimum recommended intake of essential elements for vulnerable population subgroups. It therefore follows that, based on the Tolerable Upper Intake Level (UL) values, the weekly consumption of $150 \mathrm{~g}$ or $75 \mathrm{~g}$ of seal muscle respectively would not lead to excessive intake of any of these essential elements (Table 3, Table S15).

Based on the \% RDA values, the consumption of a weekly portion of adult seal liver would be a good source of $\mathrm{Cu}$ (93\% for children; $63 \%$ for pregnant women) but would provide more than the minimum recommended intake for Se (742\% for children; $495 \%$ for pregnant women). Indeed, based on the UL values for scenarios with adult seal liver, a weekly serving

391 would exceed the recommended maximum values for Se for children 1- 3 years old (165\%).

392 Based on scenarios with winter YY liver, a weekly portion would be a good dietary source of $\mathrm{Cu}$ 393 (80\% for children; $55 \%$ for pregnant women) and Fe (95\% for children; $49 \%$ for pregnant 394 women) and would not lead to excessive intake of any of these essential elements (\% UL $<100)$.

\subsubsection{Reference values for non-essential trace elements}

Several non-essential trace elements were detected in grey seal tissues in this study,

397 including As (muscle, heart, kidney), Cd (liver, kidney), $\mathrm{Pb}$ (kidney), and $\mathrm{THg}$ and $\mathrm{MeHg}$

398 (muscle, liver, heart, kidney). When detected, the concentrations of As were less than $1 \mu \mathrm{g} / \mathrm{g}$ 399 (mean $<0.3 \mu \mathrm{g} / \mathrm{g}$, range $0.05-0.75$ ), and well below the Canadian reference value of $3.5 \mu \mathrm{g} / \mathrm{g}$

400 for $\mathrm{As}$ in food. When detected, all $\mathrm{Pb}$ concentrations were below the Canadian reference value of $401 \quad 0.05 \mu \mathrm{g} / \mathrm{g}$ for fish protein. Cd was not detected in muscle or heart tissues, but was detected in $40261 \%$ of liver samples and $100 \%$ of kidney samples. Although there is no Canadian reference 403 value for $\mathrm{Cd}$ in food, other studies on cervids have used an intake limit of 1.0 or $1.5 \mu \mathrm{g} / \mathrm{g}$ for $\mathrm{Cd}$ 404 following guidelines from the World Health Organization (Robillard et al., 2002; Stansley et al., 405 1991). None of the liver samples from winter YY exceeded the $1.5 \mu \mathrm{g} \mathrm{Cd} / \mathrm{g}$ value. For the other age categories, $20 \%$ of liver $(n=11 / 54)$ and $29 \%$ of kidney samples $(n=9 / 31$, Group 2 only)

407 exceeded this $1.5 \mu \mathrm{g} \mathrm{Cd} / \mathrm{g}$ intake limit (Table 3).

408 The reference value for $\mathrm{THg}$ in Canada is either $0.5 \mu \mathrm{g} / \mathrm{g}$ for most commercially sold fish 409 products or $1.0 \mu \mathrm{g} / \mathrm{g}$ for a few species, including fresh/frozen tuna, shark, swordfish, marlin, 410 orange roughy and escolar (Canada, 2007). In the present study, as shown in Fig. 4, none of the 411 muscle samples from winter YY exceeded these recommended maximum concentrations for $412 \mathrm{THg}$ or for MeHg. For livers from winter YY, $20 \%$ and $11 \%$ of samples exceeded these 0.5 and 
$4131.0 \mu \mathrm{g} / \mathrm{g}$ values respectively based on $\mathrm{THg}$ concentrations, but none $(0 \%)$ exceeded these values

414 based on $\mathrm{MeHg}$ concentrations. For the other age categories all together, 29\% of muscle

415 samples, $100 \%$ of liver samples, $55 \%$ of kidney samples, and $3.2 \%$ of the heart samples

416 exceeded $0.5 \mu \mathrm{g} / \mathrm{g}$ of THg. However, these proportions were lower when compared to $\mathrm{MeHg}$,

417 specifically $27 \%$ for muscle, $15 \%$ for liver, $22 \%$ for kidney, and $0 \%$ for heart tissues. When

418 comparing to the $1.0 \mu \mathrm{g} \mathrm{THg} / \mathrm{g}$ reference value, percentages were much lower, namely $5.9 \%$ for

419 muscle, $3.8 \%$ for liver, and $0 \%$ for kidney and heart tissues. Although samples from adult male

420 seals more frequently exceeded these reference values for $\mathrm{THg}$ and $\mathrm{MeHg}$ in the liver, this trend

421 may have been influenced by the small number of adult females $(n=11)$ compared to males

$422(\mathrm{n}=37)$. As presented earlier, Hg concentration was found to be slightly higher for male seals, but

423 did not show a significant increase with age after 5 months. Indeed, for $\mathrm{MeHg}$ in muscle

424 samples, there were almost equal numbers of spring YY, juveniles and adults sample that

425 exceeded the $0.5 \mu \mathrm{g} / \mathrm{g}$ value $(36 \%, 36 \%$ and $28 \%$ respectively).

\section{DISCUSSION}

\subsection{Age, sex and site-specific differences in trace element concentrations}

In this study, we did not observe progressive bioaccumulation of trace elements with age

430 bioaccumulation in grey seals in the present study showed two distinct groups based on age

431 category; winter young-of-the-year (winter YY, $<6$ weeks old) and all other age categories

432 together (Figs. 2, 4). Although there are several routes of exposure for trace elements, the

433 primary route of uptake in seals is through food (Das et al., 2002), hence these results likely

434 reflect a change in diet following weaning. The lack of significant differences in most trace

435 elements concentrations among spring young-of-the-year (spring YY, 5-6 months), juveniles (1 -

4364 years) and adults (11 - 29 years) suggest a similar diet after weaning for a broad range of ages

437 of grey seals in the GSL. Indeed, a previous study from the same region showed no significant

438 difference in grey seals' diet as a function of age with seals from 1 - 33 years old (Hammill et al.,

439 2014). Although many studies on marine mammals show gradual and continuous

440 bioaccumulation for $\mathrm{Cd}, \mathrm{Se}, \mathrm{THg}$, and $\mathrm{MeHg}$ with age (Marino et al., 2011; Dehn et al., 2005;

441 Bustamante et al., 2004; Dietz et al., 1996), this is not universally observed and lack of such

442 trends may be due to species- or tissue-specific differences or the influence of study design 
443 (sample size, age range of seals, geographic area, or concentration range) (Lahaye et al., 2006;

444 Fant et al., 2001). The lack of association of trace element concentrations with exact age (years)

445 in this study also suggests that dietary uptake of potentially toxic elements $(\mathrm{Cd}, \mathrm{THg}, \mathrm{MeHg})$

446 remains in equilibrium with physiological detoxification processes (Dehn et al., 2005).

We could not thoroughly test age-dependent bioaccumulation in the hearts and kidneys as these tissues were only sampled for two age categories. These tissues would need to be sampled from all age classes to better understand age-dependent trends. However, renal $\mathrm{Cd}$ and $\mathrm{Se}$ concentrations increased significantly from spring YY (5 - 6 months old) to juvenile seals (1 - 4

451 years old) likely indicating a progressive increase with age for these two elements.

In addition, and in contrast to $\mathrm{Cd}, \mathrm{Se}, \mathrm{THg}$ and $\mathrm{MeHg}$, some essential elements were

453 higher in the livers $(\mathrm{Fe}, \mathrm{Mg}, \mathrm{Zn})$ and muscles $(\mathrm{Cu})$ of winter $\mathrm{YY}(<6$ weeks old) when compared

454 to juvenile and adult seals. Previous studies have also observed higher concentrations of $\mathrm{Cu}$ and

455 Zn in young marine mammals (Das et al., 2002; Watanabe et al., 1998) which can be explained

456 by an increase in essential elements during development for tissue differentiation and growth, or

457 possibly by the limited excretion mechanisms of the fetus (Dehn et al., 2005; Wagemann et al., 458 1998).

Sex-specific differences in trace element bioaccumulation were not very pronounced in 460 the present study. A few elements were $\sim 30-70 \%$ more concentrated in the liver (Mn, $\mathrm{Zn})$ or 461 muscle (THg, MeHg) tissues of male seals. These observed differences between the sexes could 462 be due to size dimorphism, as male grey seals can weight up to $290 \mathrm{~kg}$ and females usually do 463 not exceed $190 \mathrm{~kg}$ (Bustamante et al., 2004), or to physiological or metabolic dimorphism

464 (Caurant et al., 1994; Robinson et al., 2012). Sex-related differences could also be due to 465 differences in foraging behaviour between the sexes. Male grey seals in the GSL have been 466 shown to eat a greater proportion of higher trophic-level fish, such as cod and hake, which likely 467 have higher mercury concentrations than lower trophic-level species, like sandlance and herring, 468 which are consumed in greater proportions by female seals (Hammill et al., 2014). 
about the influence of sample site on bioaccumulation in the present study because of the study design. Future studies may wish to examine the influence of harvest location on bioaccumulation in more detail, however it is important to note that grey seals from the GSL and the Northwest Atlantic are considered a single population and sampling sites do not represent distinct populations (Government of Canada, 2016b).

\subsection{Tissue-specific differences in trace element concentrations}

Tissue-specific bioaccumulation patterns have been observed in many previous studies on marine mammals where most trace elements concentrate to the liver and $\mathrm{Cd}$ concentrates to the kidney (AMAP, 1998; Nyman et al., 2002; Bustamante et al., 2004). Our results for grey seals mirrored this trend, with many elements $(\mathrm{Cu}, \mathrm{Co}, \mathrm{Fe}, \mathrm{Mn}, \mathrm{Mo}, \mathrm{THg}, \mathrm{Se}, \mathrm{Zn})$ more concentrated in the liver, and $\mathrm{Cd}$ highest in the kidney. Liver $\mathrm{THg}$ concentrations in the present study were 31 times higher on average than those in muscle tissues from the same seal, which is close to trends observed in ringed seals in northern Canada (Braune et al., 2015). Trace elements concentrate in the liver due to this organ's role in the homeostatic regulation of essential trace elements and the sequestration of non-essential and toxic trace elements (Hansen et al., 2016), whereas Cd tends to accumulate in the kidneys due to the presence of metal-binding proteins (Das et al. 2002).

$\mathrm{Pb}$ concentrations were mostly below detection limits in muscle, liver and heart tissues in

491 this study and these low levels are consistent with previous studies on marine mammals (AMAP,

492 1998; Fant et al., 2001; Nyman et al., 2002). Outliers for Pb in seal muscle $(\mathrm{n}=8)$ and heart $(\mathrm{n}=$

493 3) ranged from 0.08 to $0.48 \mu \mathrm{g} / \mathrm{g}$ in the present study (Fig. 3) and may indicate tissue

494 contamination from lead bullets, as observed in a previous study on moose and deer (Fachehoun

495 et al., 2015). However, harvesters in this study targeted the heads of the animals and outliers were found in samples taken from far inside the abdomen to avoid bullet fragments. One young seal (winter YY, $<6$ weeks) hunted by hakapik also had a higher than average muscle $\mathrm{Pb}$

498 concentration $(0.02 \mu \mathrm{g} \mathrm{Pb} / \mathrm{g})$. Given all of this, high $\mathrm{Pb}$ concentrations in some individuals may have been related to the use of lead bullets or to other natural or anthropogenic (e.g. lead fishing weights) sources of exposure.

Focusing on mercury, adult grey seal livers from had the highest THg concentrations (5 -

$502450 \mu \mathrm{g} / \mathrm{g}$ ) of any tissue but had very low proportions of mercury in the form of methylmercury

503 (range: 0.27 - 5.2\% MeHg). Muscle and heart tissues had much lower concentrations of $\mathrm{THg}$ 
$504(0.05-2.3 \mu \mathrm{g} / \mathrm{g})$ but had high \% MeHg ( 80\%). Kidney samples were intermediate for both $505 \mathrm{THg}$ and \% MeHg. Our results are similar to those of other studies on seals in Canada which 506 show low proportions of $\mathrm{MeHg}$ in the liver (1-12 \% MeHg in Braune et al., 2015) and higher 507 proportions in seal muscle tissues (81\% in Dehn et al., 2005). The negative correlation between 508 age category and \% $\mathrm{MeHg}$ in seal livers in this study is also consistent with previous studies 509 (cited in Ewald et al., 2019). These results, as well as the strong positive correlation between $\mathrm{Hg}$ 510 and Se in liver tissues, likely reflect detoxification mechanisms, where mercury accumulates as 511 stable and insoluble crystals of mercury selenide ( $\mathrm{HgSe})$ in the liver to protect marine mammals 512 against exposure to $\mathrm{MeHg}$ (Ewald et al., 2019; Ikemoto et al., 2004). Moreover, based on

513 toxicokinetic modeling for ringed seals in Ewald et al. (2019), cellular composition changes over 514 time and an increase in thiol-containing compounds in the liver could also lead to increased 515 partitioning of $\mathrm{MeHg}$ into inorganic $\mathrm{Hg}$ after about 4 - 5 months of age.

\subsection{Geographical and inter-species comparison}

Trace elements concentrations were in the same order of magnitude as those reported for 518 other marine mammals, namely lower tissue concentrations ( $<1.0 \mu \mathrm{g} / \mathrm{g} \mathrm{w}$.w.) for As, $\mathrm{Cr}, \mathrm{Co}, \mathrm{Pb}$, $519 \mathrm{Mo}$, and $\mathrm{Ni}$ and higher concentrations ( 1.0 - $1000 \mu \mathrm{g} / \mathrm{g}$ w.w.) for $\mathrm{Cd}, \mathrm{Cu}, \mathrm{Fe}, \mathrm{Hg}, \mathrm{Mg}, \mathrm{Mn}, \mathrm{Se}$ 520 and $\mathrm{Zn}$ in some tissues (AMAP, 1998; Bustamante et al., 2004; Frank et al., 1992). In the

521 following sections, all comparisons between studies were done using values for adult seals only 522 to reduce variation due to different age ranges. Hepatic concentrations of $\mathrm{Cu}$ and $\mathrm{Zn}$ in the 523 present study were similar to levels in other pinnipeds and grey seals from other regions 524 (Bustamante et al., 2004; Das et al., 2002). Although Fe, Mg and Mn concentrations are not 525 frequently reported in other studies, hepatic Fe concentrations for adult seals in the present study 526 (range: $65-1300 \mu \mathrm{g} / \mathrm{g}$ ) seem to be higher than previous reported values (range: $154-665 \mu \mathrm{g} / \mathrm{g}$

527 for grey seals from Sweden in Frank et al., 1992). However, the interpretation of results for Fe 528 can be challenging because organs like the liver may be congested with blood, which contains 529 large and variable quantities of Fe (Bratton et al., 2002).

530 Concentrations of As in this study (range: $0.05-0.75 \mu \mathrm{g} / \mathrm{g}$ ) were on the low end of 531 recorded values for other marine mammals (Kubota et al., 2001). Higher concentrations of As 532 are often found in the blubber, especially for marine mammals feeding on cephalopods and 533 crustaceans (Ebisuda et al., 2002), however this tissue type was not sampled in the present study. 
534 Low $\mathrm{Pb}$ levels $(<0.50 \mu \mathrm{g} / \mathrm{g}$, including outliers $)$ are consistent with previous studies on seals where concentrations $>1 \mu \mathrm{g} \mathrm{Pb} / \mathrm{g}$ were considered high and attributed to industrial pollution (O’Shea, 1999) or sample contamination (Nyman et al., 2002).

In the present study, $\mathrm{THg}$ concentration ranges in adult grey seal muscle $(0.086-1.90$ $\mu \mathrm{g} / \mathrm{g})$ were lower than ranges for grey seals from the Faroe Islands sampled in 1993 - $1995(0.13$ - $4.61 \mu \mathrm{g} / \mathrm{g}$, in Bustamante et al., 2004) and similar to ranges from Sable Island sampled in 1996 - 1998 (0.4 - $1.6 \mu \mathrm{g} / \mathrm{g}$ in Nyman et al., 2002). The mean calculated for adult seals in the present study was $0.34 \mu \mathrm{g} \mathrm{THg} / \mathrm{g}$ muscle tissue, which is in the same range as means for ringed seals from across the Canadian Arctic (0.10 - $0.69 \mu \mathrm{g} \mathrm{THg} / \mathrm{g}$ muscle tissue in Houde et al. (2020)) and

543 on the low end of averages reported in other studies of Arctic ringed seals (Brown et al., 2016;

544 Gaden et al., 2009). THg concentrations in grey seal liver are discussed in the next paragraph.

545 Most studies on pinnipeds measure only the $\mathrm{THg}$ concentrations and do not measure $\mathrm{Hg}$

546 speciation, although MeHg is a better indicator of toxic effects. To the best of our knowledge, no 547 other study has measured MeHg concentrations in grey seal organs (except for blood and milk in 548 Grajewska et al., 2019). In the present study, MeHg concentrations for adult grey seals ranged 549 from $0.10-1.84 \mu \mathrm{g} / \mathrm{g}$ in muscle and $0.11-3.00 \mu \mathrm{g} / \mathrm{g}$ in liver tissues which is similar to ranges 550 for Arctic ringed seal muscle $(0.13-1.09 \mu \mathrm{g} / \mathrm{g})$ but lower than ranges for liver $(2.50-89.9 \mu \mathrm{g} / \mathrm{g})$ 551 (Lemire et al., 2015).

552 Previous studies on grey seals have reported high renal $\mathrm{Cd}$ and hepatic $\mathrm{Hg}$ and $\mathrm{Se}$ 553 concentrations when compared to other seal species, including ringed and harbour seals 554 (Bustamante et al., 2004; Frank et al., 1992; Law et al., 1992; Nyman et al., 2002). Grey seals 555 from the Faroe Islands had renal $\mathrm{Cd}$ and hepatic $\mathrm{Hg}$ and Se levels among the highest reported in 556 the literature for temperate regions far from industrial contamination (Bustamante et al., 2004). 557 Hepatic $\mathrm{Hg}$ concentrations for adult seals in the present study (3.8 - $290 \mu \mathrm{g} / \mathrm{g})$ were similar to 558 levels in Faroe Island grey seals $(1.1-238 \mu \mathrm{g} / \mathrm{g})$ and slightly lower than grey seals from a 559 previous study of the geographically proximate Sable Island (15 - $348 \mu \mathrm{g} / \mathrm{g}$ in Nyman et al., 560 2002). These Hg concentrations in grey seal livers are higher than those for ringed seals from 561 Svalbard and the eastern Canadian Arctic, but similar to hepatic Hg levels for ringed seals in the 562 western Arctic (Fant et al., 2001; Wagemann et al., 1996). Although these studies in the 563 Canadian Arctic are from 20 years ago, a recent study shows only very limited declines in $\mathrm{Hg}$ 564 concentrations in Arctic ringed seals over the last five decades, despite declines in atmospheric 
mercury concentrations (Houde et al., 2020). Recent studies in the Canadian Arctic report average hepatic THg concentrations of 6.1 to $70.4 \mu \mathrm{g} / \mathrm{g}$ (Brown et al., 2016) and 1.8 to $27.8 \mu \mathrm{g} / \mathrm{g}$ (Houde et al., 2020) which overlap with averages calculated for juvenile and adult seals in the present study (13.8 and $31.5 \mu \mathrm{g} \mathrm{THg} / \mathrm{g}$ of liver tissue, respectively).

In the present study, renal $\mathrm{Cd}$ ranges $(0.27-4.3 \mu \mathrm{g} / \mathrm{g})$ were lower than those measured in grey seals from the Faroe Islands $(0.39$ - $155 \mu \mathrm{g} / \mathrm{g})$ and the Baltic sea (3.0 - $20 \mu \mathrm{g} / \mathrm{g})$. Renal Cd was also slightly lower than concentrations measured 20 years ago from the same grey seal population as the present study (Sable Island, range: 1.4 - $7.6 \mu \mathrm{g} / \mathrm{g}$ in (Nyman et al., 2002). Renal $\mathrm{Cd}$ in the present study was also lower compared with seals and other marine mammals from the North American Arctic where Cd bioaccumulation is known to be higher $(>10 \mu \mathrm{g} / \mathrm{g})$ in the liver and kidney, likely related to consumption of marine invertebrates such as amphipods (Brunborg et al., 2006; AMAP, 1998; Dietz et al., 1996). For example, average renal Cd ranged from 1.97 to $21.5 \mu \mathrm{g} / \mathrm{g}$ for ringed seal populations in Brown et al. (2016) compared to an average of 1.08 $\mu \mathrm{g} / \mathrm{g}$ for adults in the present study. Hepatic Se ranges in the present study $(2.2-110 \mu \mathrm{g} / \mathrm{g}$ for adult seals) were similar to those reported for grey seals from the Faroe Island $(1.2-99 \mu \mathrm{g} / \mathrm{g})$ and Sable Island $(9.3-83 \mu \mathrm{g} / \mathrm{g})$. Average hepatic Se concentrations in the present study (13.87 $\mu \mathrm{g} / \mathrm{g}$ ) were also very close to average concentrations from populations of ringed seals in the Canadian Arctic, which ranged from 3.49 to $14.7 \mu \mathrm{g} / \mathrm{g}$ in Houde et al. (2020).

\subsection{Comparison with reference values}

For essential elements, comparison to reference values based on consumption scenarios indicated that all elements were below the Recommended Dietary Allowances $(\%$ RDA $<100$ $\%$ ) for seal muscle tissues. This indicates that a weekly portion of $75 \mathrm{~g}$ (children 1 - 3 years) or $150 \mathrm{~g}$ (pregnant women 19 - 30 years) of either winter YY or adult seal meat does not pose a risk of excessive intake of essential elements for these vulnerable human population subgroups. The concentrations of many elements were higher in the liver, and therefore scenarios showed that a

590 weekly portion of winter YY liver would be an excellent source of $\mathrm{Cu}$ and Fe without exceeding

591 maximum tolerable intakes (UL) for these elements. A weekly portion of adult seal liver would 592 also be an excellent source of $\mathrm{Cu}$ but would exceeded the maximum tolerable intakes (UL) for Se 593 among children 1- 3 years old. For intakes above the UL, the potential risk of adverse effects to 
594 an individual increases but we cannot accurately estimate the proportion of the population who would experience adverse effects at any specific intake above the UL (Canada, 2005b).

However, it is important to note that Se accumulates in marine mammal livers as stable crystals of inorganic Se and $\mathrm{Hg}$ which are poorly assimilated by the intestine when ingested (Ikemoto et al., 2004). It is therefore unlikely that concentrations of Se in adult grey seal livers would result in adverse health effects related to nutrient overconsumption. We chose to use these consumption scenarios as they reflect a reasonable estimate of the average consumption of seal meat or liver in the Magdalen Islands, which is on a weekly, monthly, or more infrequent basis.

602 Seal liver is also often sold or served in pâte where it is mixed with pork liver. Elsewhere in

603 Quebec, seal products remain a delicacy served primarily in gourmet restaurants, although sport hunting for seal is gaining in popularity in Eastern Quebec. a risk for either $\mathrm{As}$ or $\mathrm{Pb}$ (despite some possible contamination by $\mathrm{Pb}$ in seal tissues). There may, however, be possible health risks associated with the moderately elevated hepatic and renal $\mathrm{Cd}$ concentrations in grey seals older than 5 months (Tables 3, S15). Importantly, as this is the age group primarily targeted during commercial hunts, none of the muscle samples from winter YY

610 seals (<6 weeks old) exceeded the recommended maximum concentrations for $\mathrm{THg}$ and $\mathrm{MeHg}$.

611 Moreover, although a few liver samples from winter YY exceeded maximum concentrations for

$612 \mathrm{THg}$, none of the liver samples exceeded the maximum concentrations when considering $\mathrm{MeHg}$.

613 For the other age classes (i.e. grey seals that have started feeding at sea), the majority of muscle

614 (71\%) and heart (97\%) samples were below the recommended value of $0.5 \mu \mathrm{g} / \mathrm{g}$ for both $\mathrm{THg}$

615 and $\mathrm{MeHg}$, but the majority of liver (100\%) and kidney (55\%) samples exceeded this maximum

616 concentration for $\mathrm{THg}$. However, $\mathrm{Hg}$ speciation analyses indicate that the percentage of $\mathrm{MeHg}$ in

617 liver and kidney is much lower than in muscle and that, in the end, only $15 \%$ of the liver and

$61822 \%$ of the kidney samples have $\mathrm{MeHg}$ values above the recommended value of $0.5 \mu \mathrm{g} / \mathrm{g}$, or 619 only $3.8 \%$ and $0 \%$ respectively when considering the $1.0 \mu \mathrm{g} / \mathrm{g}$ recommended value for $\mathrm{MeHg}$.

\section{CONCLUSIONS}

This study provides an exhaustive dataset on trace element bioaccumulation for grey

622 seals in the Gulf of Saint Lawrence (GSL). Although we did not observe progressive age-

623 dependent bioaccumulation, the results of this study indicate that seal age does play a major role 
624 in trace element concentration, most likely according to feeding behaviour. Indeed, our analyses

625 showed two distinct groups, the winter young-of-the-year ( $<6$ weeks old) and all older seals

626 grouped together ( $\sim 5$ months -29 years). After the start of feeding at sea, age did not appear to

627 have a marked influence on trace element concentrations (including total mercury and

628 methylmercury) likely due to similar diets over a broad range of seal ages.

629 Compared to other studies on pinnipeds, grey seals from the GSL had lower renal Cd

630 concentrations and relatively high hepatic $\mathrm{THg}$ and Se concentrations. Despite lower $\mathrm{Cd}$

631 concentrations than in other seal populations, moderately elevated Cd levels in the liver and

632 kidney of grey seals older 5 months and older suggest the need for continued vigilance regarding

633 potential health risks. Grey seal tissues were well below the Canadian reference values for As

634 and $\mathrm{Pb}$, however some outlier concentrations for $\mathrm{Pb}$ in muscle and heart tissues raise the

635 importance of promoting non-toxic ammunition for seal hunting. From a public health

636 perspective, our results also highlight the importance measuring $\mathrm{MeHg}$ instead of total $\mathrm{Hg}$ for

637 developing dietary recommendations for marine mammal consumption, such as grey seals from

638 the GSL. Although the majority of liver and kidney samples from grey seals feeding at sea were

639 above the recommended maximum values for THg in Canada, less than a quarter of samples

640 exceeded recommended values based on the MeHg concentrations. Overall, our study indicates

641 that, for winter young-of-the-year ( $<6$ weeks old), consumption of liver could be a good dietary

642 source of essential elements (primarily $\mathrm{Cu}$ and $\mathrm{Fe}$ ), and consumption of winter young-of-the-year

643 muscle and liver can be done without exceeding maximum recommended concentrations for

644 most trace elements. Ongoing discussions with regional public health professionals will help

645 develop dietary recommendations for the consumption of the muscle, heart, kidney or liver

646 tissues from older seals harvested from the GSL. 


\section{FUNDING SOURCES}

648 This work was supported by the Ministère de l'Agriculture, des Pêcheries et de l'Alimentation du

649 Québec (MAPAQ), the Canada Research Chair program (MA; \# 950230679), and the Fond de

650 recherche Québec - Nature et technologies (FRQNT) (GM; \# 272683). The Littoral Research

651 Chair (2019-2021) funded GM for this work, which is mainly funded by Sentinel North and the

652 Northern Contaminant Programme (NCP) of the Crown-Indigenous Relations and Northern

653 Affairs Canada (CIRNAC). ML is a member of Quebec Océan and also received a salary grant

654 from the Fonds de recherche du Québec - Santé (FRQS): Junior 1 (2015-2019) and Junior 2

655 (2019-2023).

\section{ACKNOWLEDGEMENTS}

We would like to thank Réjean Vigneau, Gil Thériault and members of the Association

659 des chasseurs de phoques Intra-Québec (ACPIQ) for their valuable contributions to this project.

660 Thank you to Nicolas Toupoint from MERINOV, Karine Villemaire and François Bourque from

661 the Ministère de l'Agriculture, des Pêcheries et de l'Alimentation du Québec (MAPAQ), and

662 Michael Hammill, Josée Richard and Cédric Arsenault from Fisheries and Oceans Canada

663 (DFO) for their help with this project. Thank you to Nick Schrier (Guelph) and Dominic

664 Bélanger (Montréal) for help with laboratory analyses. We acknowledge help with translation

665 from French by www.DeepL.com/Translator.

666 SUPPORTING INFORMATION

66714 pages including data tables (S1-S15) and details on quality assurance for laboratory analyses. 


\section{REFERENCES}

Association des chasseurs de phoques intra-Québec (ACPIQ, 2021. Magdalen Islands Seal Hunter Association [WWW Document]. URL http://www.chasseursdephoques.com/en (accessed 6.17.21).

AMAP, 2018. AMAP Assessment 2018: Biological Effects of Contaminants on Arctic Wildlife and Fish. Arctic Monitoring and Assessment Programme (AMAP), Tromsø, Norway.

AMAP, 1998. AMAP Assessment Report: Arctic Pollution Issues. Chapter 7: Heavy Metals. Arctic Monitoring and Assessment Programme (AMAP), Oslo, Norway.

Baril, G., Breton, Y., 1982. Pêche et tradition culturelle sur la Basse-Côte-Nord. Ministère des affaires culturelles, Direction générale du patrimoine ....

Bratton, G., Woshner, V., O,ÄôHara, T., 2002. Inorganic pollutants in Arctic marine mammals, in: Vos, J., O,ÄôShea, T., Fournier, M., Bossart, G., Bossart, G., Bossart, G. (Eds.), Toxicology of Marine Mammals, New Perspectives: Toxicology and the Environment. CRC Press. https://doi.org/10.1201/9780203165577.ch9

Braune, B., Chetelat, J., Amyot, M., Brown, T., Clayden, M., Evans, M., Fisk, A., Gaden, A., Girard, C., Hare, A., 2015. Mercury in the marine environment of the Canadian Arctic: review of recent findings. Sci. Total Environ. 509, 67-90.

Brown, T.M., Fisk, A.T., Wang, X., Ferguson, S.H., Young, B.G., Reimer, K.J., Muir, D.C.G., 2016. Mercury and cadmium in ringed seals in the Canadian Arctic: Influence of location and diet. Sci. Total Environ. 545-546, 503-511. https://doi.org/10.1016/j.scitotenv.2015.12.030

Brunborg, L.A., Graff, I.E., Frøyland, L., Julshamn, K., 2006. Levels of non-essential elements in muscle from harp seal (Phagophilus groenlandicus) and hooded seal (Cystophora cristata) caught in the Greenland Sea area. Sci. Total Environ. 366, 784-798. https://doi.org/10.1016/j.scitotenv.2005.10.020

Bustamante, P., Morales, C., Mikkelsen, B., Dam, M., Caurant, F., 2004. Trace element bioaccumulation in grey seals Halichoerus grypus from the Faroe Islands. Mar. Ecol. Prog. Ser. 267, 291-301. https://doi.org/10.3354/meps267291

Canada, H., 2007. Human Health Risk Assessment of Mercury in Fish and Health Benefits of Fish Consumption [WWW Document]. URL https:/www.canada.ca/en/healthcanada/services/food-nutrition/reports-publications/human-health-risk-assessmentmercury-fish-health-benefits-fish-consumption.html (accessed 6.7.21).

Canada, H., 2005a. Health Canada's Maximum Levels for Chemical Contaminants in Foods [WWW Document]. URL https://www.canada.ca/en/health-canada/services/foodnutrition/food-safety/chemical-contaminants/maximum-levels-chemical-contaminantsfoods.html (accessed 6.7.21).

Canada, H., 2005b. Dietary Reference Intakes Tables [WWW Document]. URL https://www.canada.ca/en/health-canada/services/food-nutrition/healthy-eating/dietaryreference-intakes/tables.html (accessed 6.7.21).

Caurant, F., Amiard, J.C., Amiard-Triquet, C., Sauriau, P.G., 1994. Ecological and biological factors controlling the concentrations of trace elements (As, $\mathrm{Cd}, \mathrm{Cu}, \mathrm{Hg}, \mathrm{Se}, \mathrm{Zn}$ ) in delphinids Globicephala melas from the North Atlantic Ocean. Mar. Ecol. Prog. Ser. 103, 207-219. 
Das, K., Debacker, V., Pillet, S., Bouquegneau, J.-M., 2002. Heavy metals in marine mammals, in: Toxicology of Marine Mammals. CRC Press. https://doi.org/10.1201/9780203165577.ch7

Dehn, L.-A., Sheffield, G.G., Follmann, E.H., Duffy, L.K., Thomas, D.L., Bratton, G.R., Taylor, R.J., O'Hara, T.M., 2005. Trace elements in tissues of phocid seals harvested in the Alaskan and Canadian Arctic: influence of age and feeding ecology. Can. J. Zool. 83, 726-746.

Dietz, R., Riget, F., Johansen, P., 1996. Lead, cadmium, mercury and selenium in Greenland marine animals. Sci. Total Environ. 186, 67-93. https://doi.org/10.1016/00489697(96)05086-3

Ebisuda, K., Kunito, T., Kubota, R., Tanabe, S., 2002. Arsenic concentrations and speciation in the tissues of ringed seals (Phoca hispida) from Pangnirtung, Canada. Appl. Organomet. Chem. 16, 451-457. https://doi.org/10.1002/aoc.319

Ewald, J.D., Kirk, J.L., Li, M., Sunderland, E.M., 2019. Organ-specific differences in mercury speciation and accumulation across ringed seal (Phoca hispida) life stages. Sci. Total Environ. 650, 2013-2020. https://doi.org/10.1016/j.scitotenv.2018.09.299

Fachehoun, R.C., Lévesque, B., Dumas, P., St-Louis, A., Dubé, M., Ayotte, P., 2015. Lead exposure through consumption of big game meat in Quebec, Canada: risk assessment and perception. Food Addit. Contam. Part A 32, 1501-1511.

Fant, M.L., Nyman, M., Helle, E., Rudbäck, E., 2001. Mercury, cadmium, lead and selenium in ringed seals (Phoca hispida) from the Baltic Sea and from Svalbard. Environ. Pollut. 111, 493-501. https://doi.org/10.1016/S0269-7491(00)00078-6

Fraga, C.G., 2005. Relevance, essentiality and toxicity of trace elements in human health. Mol. Aspects Med. 26, 235-244.

Frank, A., Galgan, V., Roos, A., Olsson, M., Petersson, L., Bignert, A., 1992. Metal Concentrations in Seals from Swedish Waters. AMBIO J. Hum. Environ. 21, 529-538.

Frie, A.K., Hammill, M.O., Hauksson, E., Lind, Y., Lockyer, C., Stenman, O., Svetocheva, O., 2013. Error patterns in age estimation and tooth readability assignment of grey seals (Halichoerus grypus): results from a transatlantic, image-based, blind-reading study using known-age animals. ICES J. Mar. Sci. 70, 418-430. https://doi.org/10.1093/icesjms/fss169

Gaden, A., Ferguson, S.H., Harwood, L., Melling, H., Stern, G.A., 2009. Mercury Trends in Ringed Seals (Phoca hispida) from the Western Canadian Arctic since 1973: Associations with Length of Ice-Free Season. Environ. Sci. Technol. 43, 3646-3651. https://doi.org/10.1021/es803293z

Government of Canada, 2016a. Statistics on the seal harvest [WWW Document]. URL https://www.dfo-mpo.gc.ca/Fisheries-Peches/Seals-Phoques/Seal-Stats-PhoquesEng.Html (accessed 6.17.21).

Government of Canada, 2016b. Stock assessment of Canadian Northwest Atlantic Grey Seals (Halichoerus grypus) 14.

Grajewska, A., Falkowska, L., Saniewska, D., Pawliczka, I., 2019. Changes in total mercury, methylmercury, and selenium blood levels during different life history stages of the Baltic grey seal (Halichoerus grypus grypus). Sci. Total Environ. 676, 268-277. https://doi.org/10.1016/j.scitotenv.2019.04.204

Hadley, W., 2016. Ggplot2: Elegrant graphics for data analysis. Springer. 
Hammill, M.O., den Heyer, C.E., Bowen, W.D., Lang, S.L.C., 2017. Grey Seal Population Trends in Canadian Waters, 1960-2016 and harvest advice. (No. Doc. 2017/052.). DFO Can. Sci. Advis. Sec. Res.

Hammill, M.O., Stenson, G.B., Swain, D.P., Benoît, H.P., 2014. Feeding by grey seals on endangered stocks of Atlantic cod and white hake. ICES J. Mar. Sci. 71, 1332-1341. https://doi.org/10.1093/icesjms/fsu123

Hansen, A.M.K., Bryan, C.E., West, K., Jensen, B.A., 2016. Trace element concentrations in liver of 16 species of cetaceans stranded on Pacific Islands from 1997 through 2013. Arch. Environ. Contam. Toxicol. 70, 75-95. https://doi.org/10.1007/s00244-015-0204-1

Houde, M., Taranu, Z.E., Wang, X., Young, B., Gagnon, P., Ferguson, S.H., Kwan, M., Muir, D.C.G., 2020. Mercury in Ringed Seals (Pusa hispida) from the Canadian Arctic in Relation to Time and Climate Parameters. Environ. Toxicol. Chem. 00, 1-13. https://doi.org/10.1002/etc.4865

Ikemoto, T., Kunito, T., Tanaka, H., Baba, N., Miyazaki, N., Tanabe, S., 2004. Detoxification Mechanism of Heavy Metals in Marine Mammals and Seabirds: Interaction of Selenium with Mercury, Silver, Copper, Zinc, and Cadmium in Liver. Arch. Environ. Contam. Toxicol. 47. https://doi.org/10.1007/s00244-004-3188-9

Kubota, R., Kunito, T., Tanabe, S., 2001. Arsenic accumulation in the liver tissue of marine mammals. Environ. Pollut. 115, 303-312. https://doi.org/10.1016/S0269-7491(01)000999

Lahaye, V., Bustamante, P., Dabin, W., Van Canneyt, O., Dhermain, F., Cesarini, C., Pierce, G.J., Caurant, F., 2006. New insights from age determination on toxic element accumulation in striped and bottlenose dolphins from Atlantic and Mediterranean waters. Mar. Pollut. Bull. 52, 1219-1230. https://doi.org/10.1016/j.marpolbul.2006.02.020

Law, R.J., Jones, B.R., Baker, J.R., Kennedy, S., Milne, R., Morris, R.J., 1992. Trace metals in the livers of marine mammals from the Welsh coast and the Irish Sea. Mar. Pollut. Bull. 24, 296-304. https://doi.org/10.1016/0025-326X(92)90590-3

Lemire, M., Kwan, M., Laouan-Sidi, A.E., Muckle, G., Pirkle, C., Ayotte, P., Dewailly, E., 2015. Local country food sources of methylmercury, selenium and omega-3 fatty acids in Nunavik, Northern Quebec. Sci. Total Environ. 509-510, 248-259. https://doi.org/10.1016/j.scitotenv.2014.07.102

Lesage, V., Hammill, M.O., Kovacs, K.M., 2001. Marine mammals and the community structure of the Estuary and Gulf of St Lawrence, Canada: evidence from stable isotope analysis. Mar. Ecol. Prog. Ser. 210, 203-221. https://doi.org/10.3354/meps210203

Marino, K.B., Hoover-Miller, A., Conlon, S., Prewitt, J., O’Shea, S.K., 2011. Quantification of total mercury in liver and heart tissue of Harbor Seals (Phoca vitulina) from Alaska USA. Environ. Res. 111, 1107-1115. https://doi.org/10.1016/j.envres.2011.07.010

Morissette, L., Hammill, M.O., Savenkoff, C., 2006. The Trophic Role of Marine Mammals in the Northern Gulf of St. Lawrence. Mar. Mammal Sci. 22, 74-103. https://doi.org/10.1111/j.1748-7692.2006.00007.x

Noren, S.R., Boness, D.J., Iverson, S.J., McMillan, J., Bowen, W.D., 2008. Body Condition at Weaning Affects the Duration of the Postweaning Fast in Gray Seal Pups ( Halichoerus grypus ). Physiol. Biochem. Zool. 81, 269-277. https://doi.org/10.1086/528777

Nyman, M., Koistinen, J., Fant, M.L., Vartiainen, T., Helle, E., 2002. Current levels of DDT, $\mathrm{PCB}$ and trace elements in the Baltic ringed seals (Phoca hispida baltica) and grey seals 
(Halichoerus grypus). Environ. Pollut. 119, 399-412. https://doi.org/10.1016/S02697491(01)00339-6

O’Shea, T.J., 1999. Environmental contaminants and marine mammals. Biol. Mar. Mamm. 485563.

Pintal, J.-Y., 2003. Préhistoire de la chasse au phoque dans le détroit de Belle-Isle. Rech. Amérindiennes Au Qué. 33, 35.

R Core Team, 2020. R: A language and environment for statistical computing. R Foundation for Statistical Computing, Vienna, Austria. URL https://www.R-project.org/.

Robillard, S., Beauchamp, G., Paillard, G., Bélanger, D., 2002. Levels of Cadmium, Lead, Mercury and 137caesium in Caribou (Rangifer tarandus) Tissues from Northern Québec. ARCTIC 55, 1-9. https://doi.org/10.14430/arctic686

Robinson, S.A., Lajeunesse, M.J., Forbes, M.R., 2012. Sex Differences in Mercury Contamination of Birds: Testing Multiple Hypotheses with Meta-Analysis. Environ. Sci. Technol. 46, 7094-7101. https://doi.org/10.1021/es204032m

Stansley, W., Roscoe, D.E., Hazen, R.E., 1991. Cadmium contamination of deer livers in New Jersey; human health risk assessment. Sci. Total Environ. 107, 71-82. https://doi.org/10.1016/0048-9697(91)90250-I

Swain, D.P., Richard, D., Rolland, N., Aubry, É., 2019. Évaluation du stock de morue franche (Gadus morhua) du sud du Golfe du Saint-Laurent, divisions 4T et 4Vn (novembre à avril) de l'OPANO, mars 2019. (No. Doc. de rech. 2019/038.). Secr. can. de consult. sci. du MPO.

Wagemann, R., Innes, S., Richard, P.R., 1996. Overview and regional and temporal differences of heavy metals in Arctic whales and ringed seals in the Canadian Arctic. Sci. Total Environ. 186, 41-66. https://doi.org/10.1016/0048-9697(96)05085-1

Wagemann, R., Trebacz, E., Boila, G., Lockhart, W., 1998. Methylmercury and total mercury in tissues of arctic marine mammals. Sci. Total Environ. 218, 19-31.

Watanabe, I., Tanabe, S., Amano, M., Miyazaki, N., Petrov, E.A., Tatsukawa, R., 1998. AgeDependent Accumulation of Heavy Metals in Baikal Seal (Phoca sibirica) from the Lake Baikal. Arch. Environ. Contam. Toxicol. 35, 518-526. https://doi.org/10.1007/s002449900411 


\section{Figures}

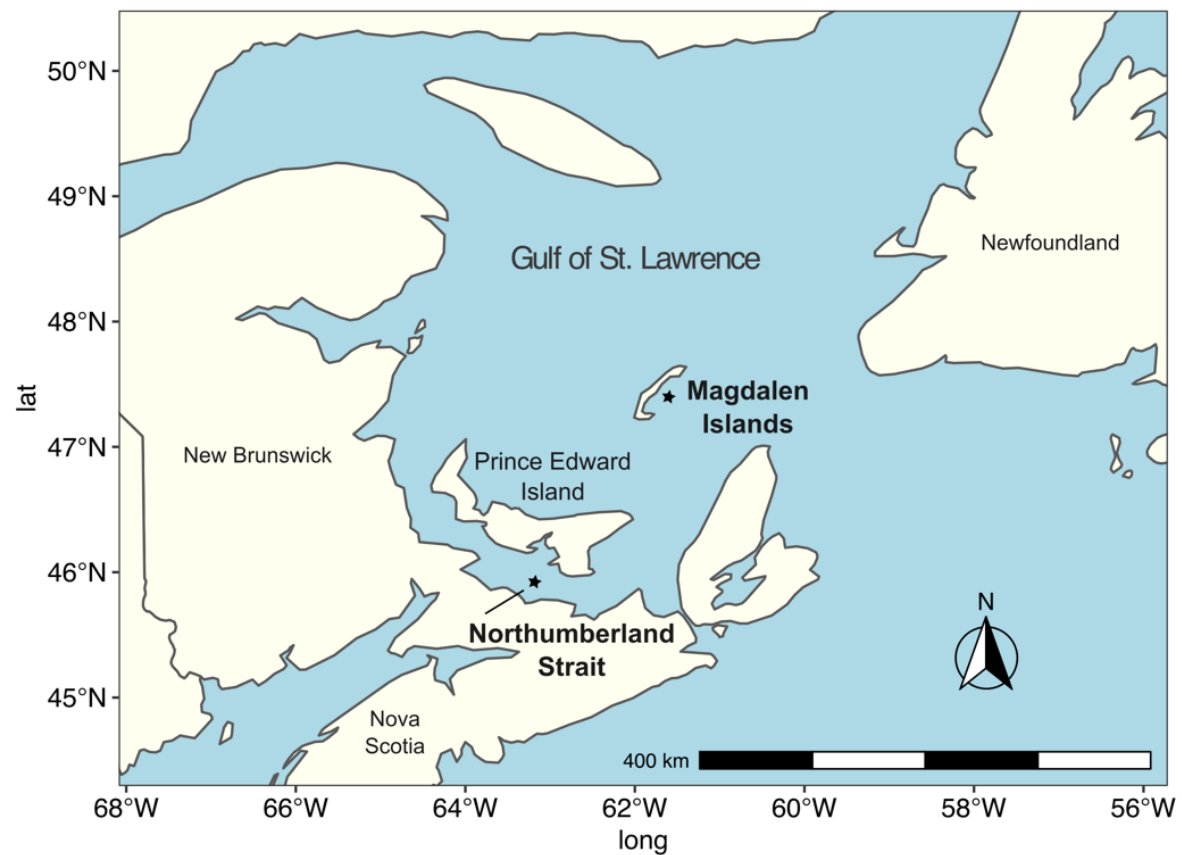

\begin{tabular}{rr|rrr|r|r|} 
& & \multicolumn{2}{|c|}{$\begin{array}{c}\text { Group 1 } \\
\text { (Winter) }\end{array}$} & & $\begin{array}{l}\text { Group 2 } \\
\text { (Spring) }\end{array}$ & \\
\hline Site & Year & 2015 & 2017 & 2018 & 2019 & Total \\
& Island 1 & 0 & 16 & 0 & 31 & 47 \\
& Island 2 & 17 & 0 & 13 & 0 & 30 \\
& Island 3 & 0 & 0 & 8 & 0 & 8 \\
\hline Sex & Island 4 & 7 & 8 & 20 & 0 & 35 \\
\hline \multirow{2}{*}{ Age } & Male & 9 & 17 & 18 & 15 & 59 \\
& Female & 0 & 7 & 23 & 16 & 46 \\
& Non-identified & 15 & 0 & 0 & 0 & 15 \\
\hline & Adult & 7 & 22 & 19 & 0 & 48 \\
& Juvenile & 2 & 2 & 2 & 11 & 17 \\
& Winter YY & 15 & 0 & 20 & 0 & 35 \\
& Spring YY & 0 & 0 & 0 & 20 & 20 \\
& Total by year & 24 & 24 & 41 & 31 & 120
\end{tabular}

Figure 1. Left: Map showing grey seal sampling sites in the Gulf of the St. Lawrence ( $n=120)$. Islands 1 and 2 are located near the Magdalen Islands and Islands 3 and 4 are location in the Northumberland Strait. Right: Table of the number of grey seals sampled by year, site, sex and age category. Trace elements were analyzed in muscle and liver tissues for Group 1 and in muscle, heart and kidney tissues for Group 2. 
Table 1. Summary table for sample size (n), geometric means, geometric 95\% confidence intervals (95\% CI: lower limit, upper limit), and range (minimum maximum) for trace element concentrations in $\mu \mathrm{g} / \mathrm{g} \mathrm{w} . \mathrm{w}$. measured in grey seals (Halichoerus grypus). Concentrations shown by age category and tissue type. Age categories were grouped into seals older than 5 months (adult, juvenile, spring YY seals, $\sim 5$ months to 29 years) and seals younger than 6 weeks (winter YY). Concentrations are reported for analytes where more than $60 \%$ of samples were detected and concentrations under the LOD were replaced with half the LOD.

\begin{tabular}{|c|c|c|c|c|c|c|c|c|c|c|c|c|c|}
\hline Muscle & & $\mathrm{n}$ & Cd & $\mathrm{Cr}$ & Co & $\mathrm{Cu}$ & $\mathrm{Fe}$ & $\mathbf{P b}$ & Mg & Mn & Mo & Se & $\mathbf{Z n}$ \\
\hline \multirow{3}{*}{$>5$ months } & Mean & 85 & n.d. & n.d. & n.d. & 1.15 & 173 & n.d. & 262 & n.d. & n.d. & 0.385 & 36.5 \\
\hline & $95 \% \mathrm{CI}$ & & n.d. & n.d. & n.d. & $(1.10,1.20)$ & $(164,183)$ & n.d. & $(254,270)$ & n.d. & n.d. & $(0.369,0.401)$ & $(34.4,38.6)$ \\
\hline & Range & & n.d. & n.d. & n.d. & $0.75-1.80$ & $87-350$ & $<$ LOD -0.48 & $180-380$ & n.d. & n.d. & $0.24-0.66$ & $18-92$ \\
\hline \multirow[t]{3}{*}{$<6$ weeks } & Mean & 34 & n.d. & n.d. & n.d. & 1.29 & 66.8 & n.d. & 222 & n.d. & n.d. & 0.340 & 39.9 \\
\hline & $95 \% \mathrm{CI}$ & & n.d. & n.d. & n.d. & $(1.21,1.37)$ & $(61.6,72.4)$ & n.d. & $(210,235)$ & n.d. & n.d. & $(0.312,0.370)$ & $(37.6,42.3)$ \\
\hline & Range & & n.d. & n.d. & n.d. & $0.82-1.80$ & $46-150$ & $<$ LOD -0.20 & $160-320$ & n.d. & n.d. & $0.20-0.57$ & $27-59$ \\
\hline \multirow[t]{3}{*}{ Total } & Mean & 119 & n.d. & n.d. & n.d. & 1.19 & 132 & n.d. & 250 & n.d. & n.d. & 0.371 & 37.4 \\
\hline & $95 \% \mathrm{CI}$ & & n.d. & n.d. & n.d. & $(1.15,1.23)$ & $(120,144)$ & n.d. & $(243,258)$ & n.d. & n.d. & $(0.357,0.386)$ & $(35.8,39.1)$ \\
\hline & Range & & n.d. & n.d. & n.d. & $0.75-1.80$ & $46-350$ & $<$ LOD -0.48 & $160-380$ & n.d. & n.d. & $0.20-0.66$ & $18-92$ \\
\hline \multicolumn{14}{|l|}{ Liver } \\
\hline \multirow[t]{3}{*}{$>5$ months } & Mean & 54 & 1.07 & 0.559 & 0.0128 & 31.4 & 294 & n.d. & 192 & 4.12 & 0.530 & 12.7 & 65.7 \\
\hline & $95 \% \mathrm{CI}$ & & $(0.881,1.30)$ & $(0.459,0.680)$ & $(0.0114,0.0143)$ & $(26.8,36.7)$ & $(253,340)$ & n.d. & $(187,197)$ & $(3.86,4.39)$ & $(0.495,0.567)$ & $(9.87,16.3)$ & $(59.4,72.7)$ \\
\hline & Range & & $0.28-51$ & $0.25-2.6$ & $<$ LOD -0.027 & $7.2-83$ & $65-1300$ & $<$ LOD -0.048 & $150-230$ & $2.4-6.4$ & $0.29-0.87$ & $2.2-110$ & $20-150$ \\
\hline \multirow[t]{3}{*}{$<6$ weeks } & Mean & 35 & n.d. & 0.410 & n.d. & 25.5 & 619 & n.d. & 220 & 3.16 & 0.393 & 0.727 & 111 \\
\hline & $95 \% \mathrm{CI}$ & & n.d. & $(0.335,0.502)$ & n.d. & $(22.2,29.2)$ & $(502,763)$ & n.d. & $(214,227)$ & $(3.02,3.32)$ & $(0.368,0.419)$ & $(0.670,0.789)$ & $(103,119)$ \\
\hline & Range & & n.d. & $<\mathrm{LD}-1.1$ & $<$ LOD -0.011 & $13-57$ & $160-1700$ & $<$ LOD -0.026 & $180-260$ & $2.4-4.6$ & $0.26-0.61$ & $0.47-1.2$ & $73-160$ \\
\hline \multirow[t]{3}{*}{ Total } & Mean & 89 & 0.245 & 0.495 & n.d. & 28.90 & 394 & n.d. & 203 & 3.71 & 0.471 & 4.12 & 80.7 \\
\hline & $95 \% \mathrm{CI}$ & & $(0.163,0.367)$ & $(0.43,0.57)$ & n.d. & $(25.9,32.3)$ & $(342,454)$ & n.d. & $(198,207)$ & $(3.53,3.91)$ & $(0.445,0.499)$ & $(2.95,5.76)$ & $(74.1,87.8)$ \\
\hline & Range & & $<$ LOD -51 & $<\mathrm{LD}-2.6$ & $<$ LOD -0.027 & $7.2-83$ & $65-1700$ & $<$ LOD -0.048 & $150-260$ & $2.4-6.4$ & $0.26-0.87$ & $0.47-110$ & $20-160$ \\
\hline \multicolumn{14}{|l|}{ Kidney } \\
\hline \multirow[t]{3}{*}{$>5$ months } & Mean & 31 & 0.986 & n.d. & 0.0107 & 2.89 & 77.3 & 0.0166 & 158 & 0.903 & 0.117 & 2.08 & 20.3 \\
\hline & $95 \% \mathrm{CI}$ & & $(0.734,1.33)$ & n.d. & $(0.00961,0.0119)$ & $(2.77,3.03)$ & $(71.3,83.7)$ & $(0.0111,0.0248)$ & $(153,164)$ & $(0.852,0.958)$ & $(0.108,0.127)$ & $(1.95,2.21)$ & $19.7,21.0)$ \\
\hline & Range & & $0.27-4.3$ & n.d. & $<$ LOD -0.026 & $2.1-3.5$ & $45-110$ & $<$ LOD -0.22 & $130-190$ & $0.58-1.2$ & $0.074-0.26$ & $1.3-2.7$ & $17-24$ \\
\hline \multicolumn{14}{|l|}{ Heart } \\
\hline \multirow[t]{3}{*}{$>5$ months } & Mean & 31 & n.d. & n.d. & n.d. & 2.79 & 87.5 & n.d. & 220 & 0.369 & 0.0323 & 0.439 & 26.5 \\
\hline & $95 \% \mathrm{CI}$ & & n.d. & n.d. & n.d. & $(2.65,2.93)$ & $(80.2,95.3)$ & n.d. & $(212,227)$ & $(0.346,0.394)$ & $(0.0302,0.0346)$ & $(0.418,0.460)$ & $(25.5,27.6)$ \\
\hline & Range & & n.d. & n.d. & n.d. & $1.9-3.4$ & $63-220$ & $<$ LOD -0.26 & $170-260$ & $0.21-0.5$ & $0.023-0.045$ & $0.32-0.64$ & $18-24$ \\
\hline
\end{tabular}



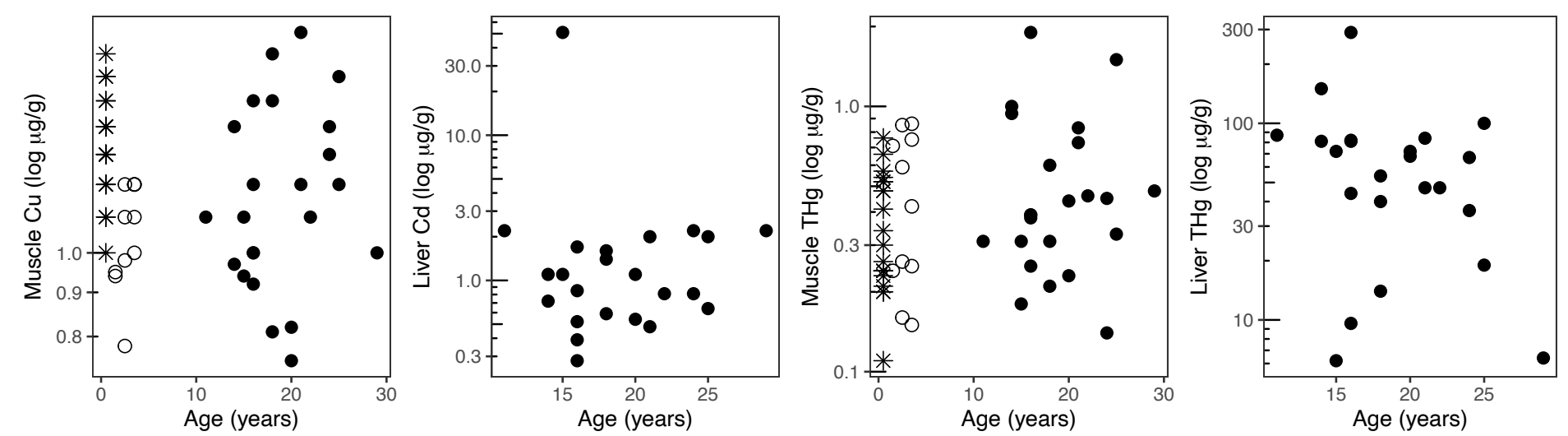

* Spring YY

O Juvenile
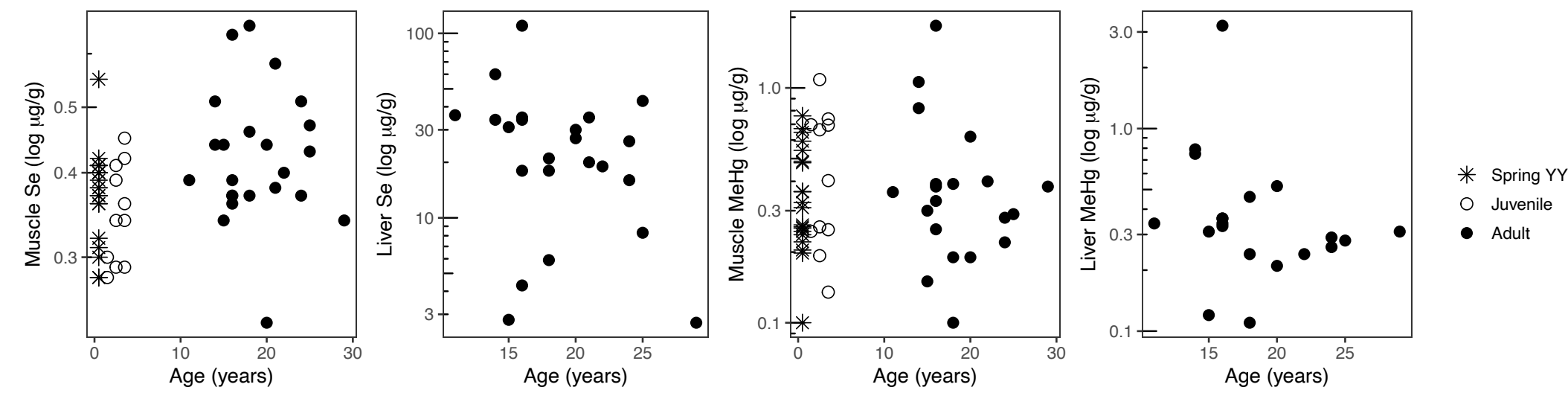

Figure 2. Correlations between exact age of grey seals (years) and selected trace element concentrations in $\log \mu \mathrm{g} / \mathrm{g} \mathrm{w} . \mathrm{w}$. for muscle (THg, MeHg) and liver (THg, $\mathrm{MeHg}, \mathrm{Cd}, \mathrm{Se}$ ) tissues. Exact age was determined for a subset of 54 seals, including 23 adults, 11 juveniles, 20 Spring YY. Sample size (n) varied for different elements: $\mathrm{n}=20-54$. No significant correlations (Pearson's $r, \mathrm{p}>0.05$ ). 
Table 2. Summary table for sample size (n), geometric means, geometric $95 \%$ confidence intervals (95\% CI: lower limit, upper limit), and range (minimum - maximum) for mercury concentrations in $\mu \mathrm{g} / \mathrm{g} \mathrm{w} . \mathrm{w}$. measured in grey seals (Halichoerus grypus). Concentrations shown by age category and tissue type. Age categories were grouped into seals older than 5 months (adult, juvenile, spring YY seals, $\sim 5$ months to 29 years) and seals younger than 6 weeks (winter YY).

\begin{tabular}{|c|c|c|c|c|c|c|c|}
\hline Muscle & & $\mathrm{n}$ & THg & $\mathrm{n}$ & MeHg & $\mathrm{n}$ & \% MeHg \\
\hline \multirow[t]{3}{*}{$>5$ months } & Mean & 85 & 0.341 & 51 & 0.353 & 51 & 85.3 \\
\hline & $95 \%$ CI & & $(0.299,0.389)$ & & $(0.298,0.419)$ & & $(83.3,87.4)$ \\
\hline & Range & & $0.086-1.90$ & & $0.100-1.84$ & & $62.1-99.9$ \\
\hline \multirow[t]{3}{*}{$<6$ weeks } & Mean & 34 & 0.0430 & 12 & 0.0710 & 12 & 76.7 \\
\hline & $95 \% \mathrm{CI}$ & & $(0.0325,0.0569)$ & & $(0.0525,0.0961)$ & & $(70.7,83.2)$ \\
\hline & Range & & $<$ LOD -0.180 & & $0.03-0.140$ & & $63.5-93.0$ \\
\hline \multirow[t]{3}{*}{ Total } & Mean & 119 & 0.189 & 63 & 0.260 & 63 & 83.6 \\
\hline & $95 \%$ CI & & $(0.153,0.233)$ & & $(0.210,0.323)$ & & $(81.5,85.8)$ \\
\hline & Range & & $<$ LOD -1.90 & & $0.03-1.84$ & & $62.1-99.9$ \\
\hline \multicolumn{8}{|l|}{ Liver } \\
\hline \multirow[t]{3}{*}{$>5$ months } & Mean & 54 & 28.7 & 26 & 0.345 & 26 & 0.795 \\
\hline & $95 \%$ CI & & $(21.9,37.6)$ & & $(0.268,0.446)$ & & $(0.549,1.15)$ \\
\hline & Range & & $3.80-290$ & & $0.110-3.22$ & & $0.270-5.16$ \\
\hline \multirow[t]{3}{*}{$<6$ weeks } & Mean & 35 & 0.283 & 19 & 0.0720 & 19 & 24.2 \\
\hline & $95 \%$ CI & & $(0.214,0.374)$ & & $(0.0554,0.0936)$ & & $(21.1,27.8)$ \\
\hline & Range & & $0.072-2.20$ & & $0.03-0.170$ & & $12.9-39.6$ \\
\hline \multirow{3}{*}{ Total } & Mean & 89 & 4.67 & & 0.178 & & 3.36 \\
\hline & $95 \%$ CI & & $(2.79,7.82)$ & 45 & $(0.133,0.239)$ & 45 & $(1.93,5.86)$ \\
\hline & Range & & $0.072-290$ & & $0.03-3.22$ & & $0.270-39.6$ \\
\hline \multicolumn{8}{|l|}{ Kidney } \\
\hline \multirow[t]{3}{*}{$>5$ months } & Mean & 31 & 0.678 & 31 & 0.266 & 31 & 33.4 \\
\hline & $95 \% \mathrm{CI}$ & & $(0.535,0.858)$ & & $(0.211,0.334)$ & & $(30.3,36.9)$ \\
\hline & Range & & $0.17-2.90$ & & $0.072-0.918$ & & $16.4-53.0$ \\
\hline \multicolumn{8}{|l|}{ Heart } \\
\hline \multirow[t]{3}{*}{$>5$ months } & Mean & 31 & 0.128 & 31 & 0.118 & 31 & 87.7 \\
\hline & $95 \% \mathrm{CI}$ & & $(0.103,0.159)$ & & $(0.0942,0.149)$ & & $(86.0,89.4)$ \\
\hline & Range & & $0.045-0.50$ & & $0.037-0.448$ & & $76.9-96.6$ \\
\hline
\end{tabular}


a)

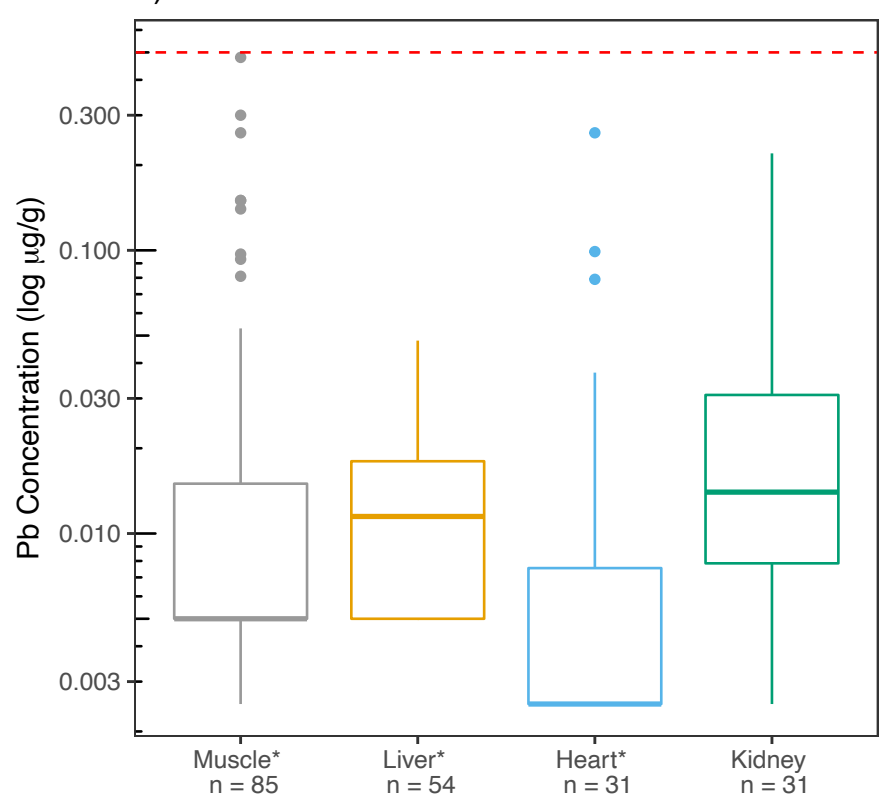

Figure 3. Concentrations in $\log _{10}$ ug/g w.w. of lead $(\mathrm{Pb})$ in grey seals by tissue type. Boxplot values are medians $( \pm 1$ st and 3rd quartiles) and points outside whiskers are outliers (outliers: muscle, $n=8$, heart, $n=3$ ). The asterisk $(*$ ) indicates that $\mathrm{Pb}$ was detected in less than $60 \%$ of muscle, liver and heart samples and values $<$ LOD were replaced with half the LOD. Dotted line shows Canadian reference value for $\mathrm{Pb}$ of $3.5 \mu \mathrm{g} / \mathrm{g}$ w.w. in food products. 
bioRxiv preprint doi: https://doi.org/10.1101/2021.08.30.458200; this version posted August 31, 2021. The copyright holder for this preprint (which was not certified by peer review) is the author/funder. All rights reserved. No reuse allowed without permission.
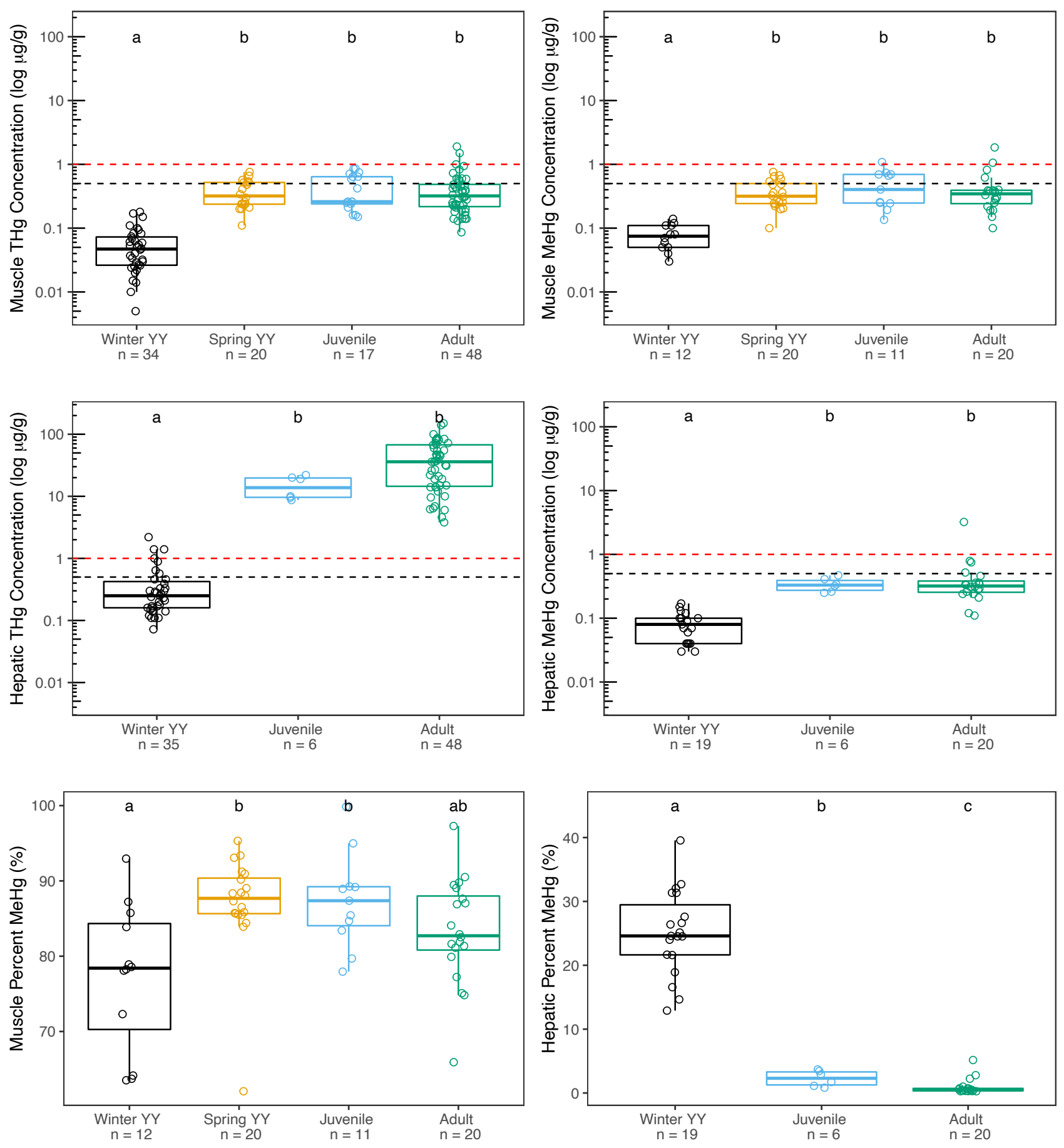

Figure 4. Concentrations in $\log _{10} \mathrm{ug} / \mathrm{g}$ w.w. of THg (left) and $\mathrm{MeHg}$ (right) in grey seal muscle and liver tissues shown by age category. Boxplot values are medians ( \pm 1 st and 3 rd quartiles) and points outside whiskers are outliers. Dotted lines indicate Canadian reference values of 0.5 (black) and 1.0 (red) $\mu \mathrm{g} / \mathrm{g}$ w.w. of THg. Letters show results of one-way ANOVAs with Post-Hoc Tukey HSD tests. 
Table 3. Comparison of grey seal essential and non-essential trace elements concentrations to Canadian reference values. For essential elements, this table shows the percentage of Tolerable Upper Intake Level (\% UL) based on consumption scenarios of $75 \mathrm{~g}$ of muscle or liver tissue weekly for children from 1 to 3 years. Levels are exceeded when \% UL is above $100 \%$. For non-essential elements, this table shows the percentage of samples above Canadian reference values for food products $(\%>$ CRV) and values are exceeded when above $0 \%$.

Essential elements : Percentage of Tolerable Upper Intake Level (\% UL) based on consumption of $75 \mathrm{~g}$ of muscle or liver tissue weekly for children from 1 to $3 \mathrm{yr}$.

Non-essential elements : Percentage of grey seal samples above Canadian reference values $(\%>\mathrm{CRV})$ for food products.

\begin{tabular}{|c|c|c|c|c|c|c|c|c|c|c|c|}
\hline \multicolumn{6}{|c|}{ Winter young-of-the-year grey seals (less than 6 weeks old) } & \multicolumn{6}{|c|}{ Winter young-of-the-year grey seals (less than 6 weeks old) } \\
\hline \multirow[b]{2}{*}{ Essential } & \multirow[b]{2}{*}{$\mathbf{U L}$} & \multicolumn{2}{|l|}{ Muscle } & \multicolumn{2}{|l|}{ Liver } & \multirow[b]{2}{*}{ Non-essential } & \multirow[b]{2}{*}{ CRV } & \multicolumn{2}{|l|}{ Muscle } & \multicolumn{2}{|l|}{ Liver } \\
\hline & & $\%$ UL & Intake & $\% \mathrm{UL}$ & Intake & & & $\%>C R V$ & $\mu \mathrm{g} / \mathrm{g}$ & $\%>\mathrm{CRV}$ & $\mu \mathrm{g} / \mathrm{g}$ \\
\hline Copper $(\mathrm{Cu})$ & $3000 \mu \mathrm{g} / \mathrm{day}$ & $1.4 \%$ & Low & $27 \%$ & Low & Arsenic (As) & $3.5 \mu \mathrm{g} / \mathrm{g}$ & $0 \%$ & As $<0.10$ & $0 \%$ & As $<0.10$ \\
\hline $\operatorname{Iron}(\mathrm{Fe})$ & $40000 \mu \mathrm{g} /$ day & $1.8 \%$ & Low & $17 \%$ & Low & Cadmium $(\mathrm{Cd})$ & $1.5 \mu \mathrm{g} / \mathrm{g}^{*}$ & $0 \%$ & $\mathrm{Cd}<0.05$ & $0 \%$ & $\mathrm{Cd}<0.05$ \\
\hline Selenium $(\mathrm{Se})$ & $150 \mu \mathrm{g} / \mathrm{day}$ & $4.0 \%$ & Low & $8.7 \%$ & Low & Lead $(\mathrm{Pb})$ & $0.5 \mu \mathrm{g} / \mathrm{g}$ & $0 \%$ & $\begin{array}{l}\mathrm{Pb}<0.05 \\
\text { one outlier }\end{array}$ & $0 \%$ & $\mathrm{~Pb}<0.03$ \\
\hline Zinc (Zn) & $12000 \mu \mathrm{g} /$ day & $6.1 \%$ & Low & $17 \%$ & Low & $\begin{array}{r}\text { Total mercury }(\mathrm{THg}) \\
\text { Methylmercury }(\mathrm{MeHg})\end{array}$ & $0.5 \mu \mathrm{g} / \mathrm{g}$ & $\begin{array}{l}0 \% \\
0 \%\end{array}$ & $\begin{array}{l}\mathrm{THg}<0.18 \\
\mathrm{MeHg}<0.14\end{array}$ & $\begin{array}{r}20 \% \\
0 \%\end{array}$ & $\begin{array}{l}\mathrm{Hg} \text { total }<2.2 \\
\mathrm{MeHg}<0.17\end{array}$ \\
\hline \multicolumn{6}{|c|}{ Adult grey seals only } & \multicolumn{6}{|c|}{ Adult, juvenile, and spring young-of-the-year grey seals } \\
\hline & & \multicolumn{2}{|l|}{ Muscle } & \multicolumn{2}{|l|}{ Liver } & & & \multicolumn{2}{|l|}{ Muscle } & \multicolumn{2}{|l|}{ Liver } \\
\hline Essential & UL & $\% \mathrm{UL}$ & Intake & $\% \mathrm{UL}$ & Intake & Non-essential & CRV & $\%>\mathrm{CRV}$ & $\mu \mathrm{g} / \mathrm{g}$ & $\%>\mathrm{CRV}$ & $\mu \mathrm{g} / \mathrm{g}$ \\
\hline Copper $(\mathrm{Cu})$ & $3000 \mu \mathrm{g} / \mathrm{day}$ & $1.2 \%$ & Low & $32 \%$ & Low & Arsenic (As) & $3.5 \mu \mathrm{g} / \mathrm{g}$ & $0 \%$ & As $<0.28$ & $0 \%$ & As $<0.10$ \\
\hline $\operatorname{Iron}(\mathrm{Fe})$ & $40000 \mu \mathrm{g} /$ day & $4.4 \%$ & Low & $8.0 \%$ & Low & Cadmium (Cd) & $1.5 \mu \mathrm{g} / \mathrm{g}^{*}$ & $0 \%$ & $\mathrm{Cd}<0.05$ & $20 \%$ & $\mathrm{Cd}<51.0$ \\
\hline Selenium $(\mathrm{Se})$ & $150 \mu \mathrm{g} / \mathrm{day}$ & $4.7 \%$ & Low & $165 \%$ & $\operatorname{High}^{* *}$ & Lead $(\mathrm{Pb})$ & $0.5 \mu \mathrm{g} / \mathrm{g}$ & $0 \%$ & $\begin{array}{l}\mathrm{Pb}<0.08 \\
\text { outliers }\end{array}$ & $0 \%$ & $\mathrm{~Pb}<0.05$ \\
\hline \multirow[t]{7}{*}{ Zinc (Zn) } & $12000 \mu \mathrm{g} /$ day & $6.0 \%$ & Low & $10 \%$ & Low & $\begin{array}{r}\text { Total mercury (THg) } \\
\text { Methylmercury (MeHg }\end{array}$ & $0.5 \mu \mathrm{g} / \mathrm{g}$ & $\begin{array}{l}29 \% \\
27 \% \\
\end{array}$ & $\begin{array}{l}\mathrm{THg}<1.90 \\
\mathrm{MeHg}<1.84 \\
\end{array}$ & $\begin{array}{r}100 \% \\
15 \% \\
\end{array}$ & $\begin{array}{r}\text { Hg total }<290 \\
\mathrm{MeHg}<3.22 \\
\end{array}$ \\
\hline & & & & & & & & \multicolumn{2}{|l|}{ Heart } & \multicolumn{2}{|l|}{ Kidney } \\
\hline & & & & & & Non-essential & CRV & $\%>\mathrm{CRV}$ & $\mu \mathrm{g} / \mathrm{g}$ & $\%>\mathrm{CRV}$ & $\mu \mathrm{g} / \mathrm{g}$ \\
\hline & & & & & & Arsenic (As) & $3.5 \mu \mathrm{g} / \mathrm{g}$ & $0 \%$ & As $<0.75$ & $0 \%$ & As $<0.63$ \\
\hline & & & & & & Cadmium $(\mathrm{Cd})$ & $1.5 \mu \mathrm{g} / \mathrm{g}^{* *}$ & $0 \%$ & $\mathrm{Cd}<0.05$ & $29 \%$ & $\mathrm{Cd}<4.3$ \\
\hline & & & & & & Lead $(\mathrm{Pb})$ & $0.5 \mu \mathrm{g} / \mathrm{g}$ & $0 \%$ & $\begin{array}{l}\mathrm{Pb}<0.01 \\
\text { outliers }\end{array}$ & $0 \%$ & $\mathrm{~Pb}<0.22$ \\
\hline & & & & & & $\begin{array}{r}\text { Total mercury }(\mathrm{THg}) \\
\text { Methylmercury }(\mathrm{MeHg}\end{array}$ & $0.5 \mu \mathrm{g} / \mathrm{g}$ & $\begin{array}{r}3.2 \% \\
0 \% \\
\end{array}$ & $\begin{array}{l}\mathrm{THg}<0.50 \\
\mathrm{MeHg}<0.45\end{array}$ & $\begin{array}{l}55 \% \\
22 \%\end{array}$ & $\begin{array}{l}\mathrm{THg}<2.9 \\
\mathrm{MeHg}<0.92\end{array}$ \\
\hline
\end{tabular}

${ }^{*}$ There is no Canadian reference value for $\mathrm{Cd}$ in food products, see section 3.3 for more details.

${ }^{* *}$ Excessive consumption of $\mathrm{Fe}$ or $\mathrm{Se}$ is unlikely to result in adverse health effects, see section 4.4 for more details. 